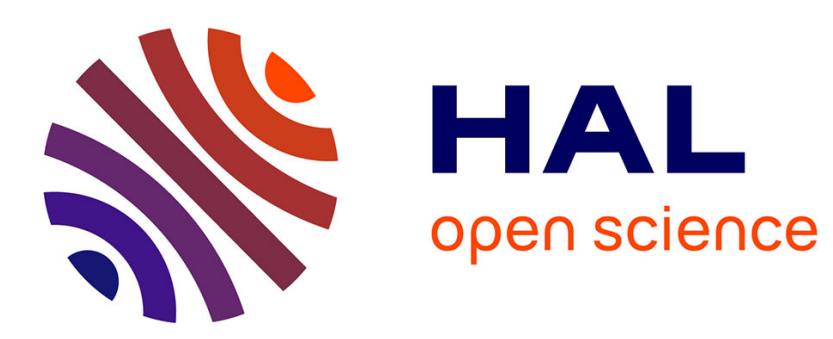

\title{
Genetics of developmental dyslexia
}

Thomas S. Scerri, Gerd Schulte-Körne

\section{- To cite this version:}

Thomas S. Scerri, Gerd Schulte-Körne. Genetics of developmental dyslexia. European Child and Adolescent Psychiatry, 2009, 19 (3), pp.179-197. 10.1007/s00787-009-0081-0 . hal-00540651

\section{HAL Id: hal-00540651 \\ https://hal.science/hal-00540651}

Submitted on 29 Nov 2010

HAL is a multi-disciplinary open access archive for the deposit and dissemination of scientific research documents, whether they are published or not. The documents may come from teaching and research institutions in France or abroad, or from public or private research centers.
L'archive ouverte pluridisciplinaire HAL, est destinée au dépôt et à la diffusion de documents scientifiques de niveau recherche, publiés ou non, émanant des établissements d'enseignement et de recherche français ou étrangers, des laboratoires publics ou privés. 


\title{
Genetics of developmental dyslexia
}

\author{
Thomas S. Scerri · Gerd Schulte-Körne
}

Received: 10 July 2009/Accepted: 15 November 2009/Published online: 29 November 2009

(C) Springer-Verlag 2009

\begin{abstract}
Developmental dyslexia is a highly heritable disorder with a prevalence of at least 5\% in school-aged children. Linkage studies have identified numerous loci throughout the genome that are likely to harbour candidate dyslexia susceptibility genes. Association studies and the refinement of chromosomal translocation break points in individuals with dyslexia have resulted in the discovery of candidate genes at some of these loci. A key function of many of these genes is their involvement in neuronal migration. This complements anatomical abnormalities discovered in dyslexic brains, such as ectopias, that may be the result of irregular neuronal migration.
\end{abstract}

Keywords Developmental dyslexia - Genetics . Reading · Spelling

\section{Introduction}

The ability to use spoken language and to read are unique attributes of Homo sapiens that set us aside from other species on the planet. Although it has been argued that language development is an innate ability, reading in contrast is not an innate ability, but is acquired through

\footnotetext{
T. S. Scerri

Wellcome Trust Centre for Human Genetics, University of Oxford, Roosevelt Drive, Oxford OX3 7BN, UK

e-mail: Thomas.scerri@well.ox.ac.uk

G. Schulte-Körne ( $\square)$

Department of Child and Adolescent Psychiatry,

Psychosomatics and Psychotherapy, University of Munich, Pettenkoferstr. 8a, 80336 Munich, Germany

e-mail: Gerd.Schulte-Koerne@med.uni-muenchen.de
}

extensive tuition. Different writing (and hence reading) systems have developed over thousands of years across the globe. The earliest known occurrence of $H$. sapiens ability to read and write dates back over 5,000 years, in a region including the present day middle east [102].

Most individuals can acquire the ability to read and write to a standard of proficient fluency and accuracy, but for at least $5 \%$ of school-aged children with the developmental dyslexia (DD; [MIM 127700]) this can be a challenging task that often persists into adulthood. DD is generally referred to as a specific impairment in reading ability that is substantially below the expected reading ability given the person's chronological age, measured intelligence and age-appropriate education. Exclusion criteria are acquired brain trauma or disease and impaired visual and auditory sensory acuity $[1,76,133,159,167$, 206, 209].

\section{Recognition of DD}

It is reported that the condition of word-blindness, also known as "wortblindheit" or "cétité verbale", was recognised 130 years ago by Kussmaul, and was loosely described as inability to read words, despite being able to see them $[82,99]$. About 30 years later, individual cases of word-blindness began to be documented in the English literature. Many of the early reports were by Hinshelwood, who described cases where the ability to read was spontaneously lost or diminished in adulthood. These cases often coincided with secondary conditions, such as a severe headache, stroke, epileptiform seizure, aphasia, hemiplegia or right homonymous hemianopsia, or else a physical strike to the head [82-85, 88]. This condition of acquired wordblindness, or alexia, was attributed to the damage of some parts of the brain. Pathological examinations confirmed this 
by revealing lesions in the left supramarginal and angular gyri of the inferior parietal lobe [82-84]. This is where cross-model integration of auditory and visual information occurs.

At the same time, congenital word-blindness (or DD) began to be recognised [86, 87, 89, 123, 181, 188]. These were cases of children, often described as healthy, bright and intelligent, who had great difficulty in learning to read and write. Given the perceived clinical similarity of DD and acquired word-blindness, it was postulated that individuals with DD would also have abnormalities in their left supramarginal and angular gyri [86].

\section{Neurobiology of DD}

Evidence for a neurobiological basis for DD comes from postmortem examinations and brain imaging of individuals with DD. Postmortem examinations of four male and three female brains with DD made two primary observations; an increase in abnormalities of the left hemisphere concentrated around the perisylvian region and near symmetry of the planum temporale [61, 63, 92]. The abnormalities included neuronal ectopias and focal architectonic dysplasias, specifically micropolygyria, of the left planum temporale. The ectopias, consisting of nest of neurones, and occasionally the dysplasias, were often found in layer I of predominantly the left inferior frontal and superior temporal gyri. An important inference from these studies was that the abnormalities, or lesions, occurred at a time of peak neuronal migration during embryonic development [63].

Subsequently, visual processing experiments indicated problems with rapid visual processing in individuals with DD. This led to the postmortem re-examination of the same DD brains as before [61, 63, 92, 108]. This revealed disorganisation of the magnocellular, but not the parvocellular, layers of the lateral geniculate nuclei (LGN). This region of the brain forms part of the primate visual system and so these observations were consistent with the visual processing deficiencies observed in DD [108]. The cell bodies comprising the magnocellular layers of the LGN from the DD brains also appeared smaller than in control brains.

Similarly, the results from auditory processing experiments indicated problems with rapid auditory processing in individuals with DD [147, 185]. This again led to the reexamination of same DD brains. This time the medial geniculate nuclei (MGN) were examined as these are involved in the auditory processing system [61-63, 92]. The DD brains presented greater asymmetry between the left and right MGN than in control brains, and generally the left MGN had more smaller and less larger neurones [62].

Much has been learnt about the processes of reading by functional neuroimaging of brains unaffected with DD.
These studies suggest that two posterior pathways exist, namely the dorsal and ventral pathways, along with an anterior component and that generally there is a bias of leftside processing. The dorsal pathway is centred on the left temporoparietal regions. It includes the angular and supramarginal gyri, and also the left posterior end of the superior temporal gyrus [173], and deals with attentionally controlled mapping of graphemes of a visual word onto phonological representation. An underactivation in this pathway is considered as correlate of a phonological deficit. The ventral pathway is centred on the left inferior occipitotemporal region and includes the posterior fusiform gyrus. It may be required for the quick automatic processing of familiar visual words or frequent letter strings within words. The under activation of this pathway in dyslexic subjects was interpreted as correlate of the slow and erroneous word recognition. The anterior component is centred on the left inferior frontal gyrus and mainly correlates with the articulation of speech sounds. An over activation in this brain region was seen as compensatory, although ineffective articulatory-based access to phonological word representations in DD [148].

Many functional neuroimaging studies have demonstrated altered activity of exactly these regions in DD brains [43]. For example, in one study, phonological and lexical tasks resulted in the activation of the left inferior temporal gyrus of most control brains, whereas almost none of the DD brains showed any activation of this region [33]. Several studies have also demonstrated reduced activity of left temporoparietal regions (including the angular and supramarginal gyri) on tasks of word reading, non-word reading and letter rhyming [171, 172, 187], and left occipitoparietal regions on tasks of letter matching [187]. A large study comparing 70 DD brains to 74 control brains similarly revealed reduced left inferior frontal, left superior temporal, left occipitotemporal and left temporoparietal regional activity on several reading-related tasks [166]. In addition, a positive correlation was observed between individual reading skill and activity in left posterior regions, for example, between pseudoword reading and the left occipitotemporal region [166]. A compensatory higher activation pattern in DD subjects was found repeatedly in the left inferior frontal brain area [21, 143, 151, 168]. Imaging studies have also identified greater asymmetry and less grey matter content of the cerebellum in DD brains [19, 45, 103], with one study indicating a smaller right anterior lobe correlates with phonological deficits [103].

Finally, it is often observed that the equivalent homotopic right hemispheres display increased activity in DD brains, perhaps as a compensatory measure. For example, the right temporoparietal regions (including the angular gyrus) displayed greater activation in response to both 
word and non-word reading [171, 172], and increased activity in the right relative to the left inferior temporal gyrus during a phonological task [33].

\section{Theories on the basis of DD}

Numerous theories and ideas have been put forward to explain the deficits observed in DD individuals, but whilst each may be supported by evidence from a few individuals with DD, not one is able to account for all cases of DD. A brief description of each is given here. The phonological deficit theory is the most widely accepted, and is explained by a problem in representing, storing or retrieving phonemes, resulting in poor or ineffectual reading [17, 177]. The rapid auditory processing theory suggests that DD develops from an auditory deficit that inhibits the perception of short or rapidly varying sounds [185]. The visual deficit theory suggests that an impairment of the visual magnocellular system, and its association with the posterior parietal cortex, is responsible for DD [179]. The cerebellar deficit theory attempts to tie in the motor deficits often associated with DD by recognising that the cerebellum is important in both movement control and the automation of skills $[50,81,126,183]$. The magnocellular (auditory and visual) theory extends upon both the auditory and visual theories by postulating that a general impairment in magnocellular pathways will affect visual, auditory and tactile sensory modalities [179]. The double-deficit hypothesis proposes that DD arises from deficits in both phonological processes and the rapid naming of simple stimuli such as words [207, 208]. A fundamental argument against each theory is that they can only explain a proportion of individuals with DD, and that some individuals with DD do not have the other peripheral deficiencies often described by these theories [145]. Indeed, it is entirely possible that each theory may account for different sub-sets of dyslexia, brought about by different aetiologies, whether they are genetic or environmental.

\section{Prevalence of DD}

The prevalence of DD, that is the occurrence of DD in the general (unselected) population, has been estimated from epidemiological studies, with large numbers of individuals, typically from Western populations, employing different selection criteria and different test languages. To illustrate this, a study of 5,718 children in a population-based birth cohort in the US has produced prevalence figures of $5.3-11.8 \%$ [96]. However, DD is not limited to Western populations. A study of 690 Chinese children from Hong Kong found prevalence rates of 9.7-12.6\% [28], and a study of reading disability in 2,878 Egyptian children found a prevalence rate of $1.3 \%$ [49]. The prevalence of
DD is often observed greater in males than in females, at a ratio of $\sim 2: 1[28,41,49,96]$, and this is often explained by an ascertainment or referral bias $[52,196]$. However, ever increasing sample sizes from unselected populations makes this argument difficult to justify. Four independent epidemiological samples $(n=989,895,5,752$ and 2,163) from a single study observed prevalences of $18.5-24.6 \%$ in boys and $8.3-13 \%$ in girls. A huge prospective study in the US of 32,223 children (16,080 boys and 16,143 girls) observed that twice as many boys were affected than girls [56], and a study of reading ability in nearly 200,000 children across 43 different countries found that in every country examined, without exception, girls outperformed boys on reading tests [30].

\section{Genetic studies on dyslexia}

\section{Familiarity of DD}

Developmental dyslexia does not just occur randomly within the population. In fact, familial clustering of DD was observed well over 100 years ago [89, 181, 188]. It was later observed that an individual's risk of being affected increased, when other family members were already affected [77]. Later, it was observed that $9 \%$ of control children had a sibling or parent with some form of reading problem, when compared with $34 \%$ of children with DD [152]. Recently, it has been shown that 20-33\% of siblings of affected individuals, with unaffected parents, are themselves also affected [67]. This increased to $54-63 \%$ if either (but not both) parent was also affected, and to $76-78 \%$ if both parents were affected [67]. For spelling disorder, the percentage of affected siblings has been found to be higher (52-62\%) than for word reading [156]. The sibling recurrence risk of DD, that is the probability of an individual being affected with DD given a sibling is already affected (regardless of parental affection status), is estimated as 43-60\% [197, 213]. With a population prevalence of $\sim 10 \%$ and a sibling recurrence risk of $\sim 50 \%$, the sibling relative risk can be estimated as between 4 and 6 , and increases with stricter affection status criteria [213].

\section{Heritability of DD}

With such a strong familial basis for DD, twin studies have been employed to evaluate the contribution of the environmental and genetic components underlying its aetiology. Typically, such studies utilise large sets of monozygotic (MZ) and same sex dizygotic twins. The concordance rate for DD is then compared between the two sets of twins. A higher concordance rate in the MZ twins 
would be suggestive of a genetic aetiology for DD, and fittingly this has been shown consistently; 1.00 versus 0.52 [212], 0.91 versus 0.45 [4] and 0.68 versus 0.38 [41]. Twin studies also enable estimates of the heritability of DD, that is the proportion of phenotypic variation attributable to genetic variation, with figures ranging from 0.30 to 0.70 [27, 42, 64, 182], depending on the diagnostic criteria, age and sample size (see Fig. 1) [38, 79, 106, 136].

Identifying the risk factors behind DD susceptibility

Twin- and family-based studies have shown that DD is highly familial and also heritable and complex, involving multiple risk factors, both genetically and environmentally $[53,58,76,133,155,159,206]$. Identifying the environmental factors has yielded interesting and controversial results, ranging from the effects of maternal antibodies [195], associations with immune disorders [69, 91, 192], fatty-acid deficiencies [36, 186], imbalances of trace and toxic metals $[24,70]$ and exposures to high levels of prenatal testosterone $[16,66]$.

Conversely, the search for genetic risk factors is yielding convincing results, as will be discussed later. However, before we touch on that, there is one more important aspect of DD to be covered is the issue of co-morbidity (see Table 1), particularly with other neurodevelopmental disorders, such as attention deficit/hyperactivity disorder (ADHD [MIM 143465]) [3], developmental dyscalculia (DC) [105], specific language impairment (SLI [MIM 606711) [118] and speech-sound disorder (SSD [MIM 608445]) [13]. ADHD is characterised by inattention, overactivity and impulsiveness and has a population prevalence of $\sim 5 \%$ [1]. DC has a population prevalence of about 3.6$6.6 \%$ and is generally defined as a specific impairment in arithmetic abilities, despite any deficits in intelligence, socioeconomical background, general motivation, emotional stability, educational opportunity or sensory acuity $[1,75,105,164,165,209]$. SLI is regarded as impairment in the ability to acquire adequate language skills, despite normal intelligence and development and has a population prevalence of approximately $2.3-7.4 \%$ between 2 and 5 years old [101, 191]. SSD, or phonological disorder, is characterised by speech-sound production errors associated with deficits in articulation, phonological processing and cognitive linguistic processing, and has an estimated population prevalence of $\sim 15 \%$ at 3 years of age, decreasing to $3 \%$ by 6 years of age $[23,170]$. There is not much evidence of increased co-morbidity between DD and SSD alone, but in conjunction with language impairments there is significant co-morbidity with DD, particularly with deficits in spelling [13, 104].

Co-morbidity with these disorders presents a challenge for researchers studying the genetics of DD. On the one hand, DD individuals recruited for these studies must be carefully vetted with strict exclusion criteria to ensure that a homogenous sample is collected without other underlying neurological disorders. However, on the other hand, from the statistics presented in Table 1, individuals with DD, depending on the diagnostic criteria used to diagnose a comorbid disorder will commonly present with another neurodevelopmental disorder, thus making pure DD individuals rare and not actually representative of the majority of individuals with this disorder. Individuals with DD will display a unique set of symptoms and severity, for both DD and any other neurodevelopmental disorder they possess. Furthermore, whether DD is causative of another neurodevelopmental disorder, or vice versa, or whether both disorders are the results of the same aetiology further
Fig. 1 Heritability estimates of reading and spelling

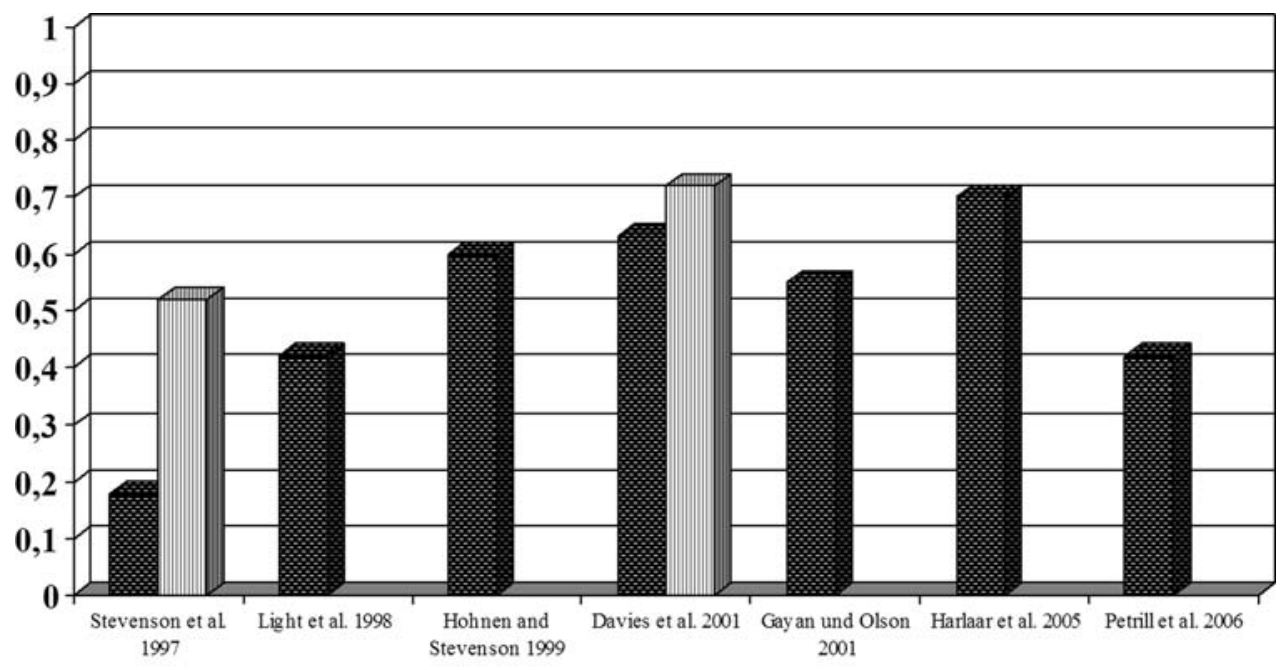

Word reading $\square$ Spelling 


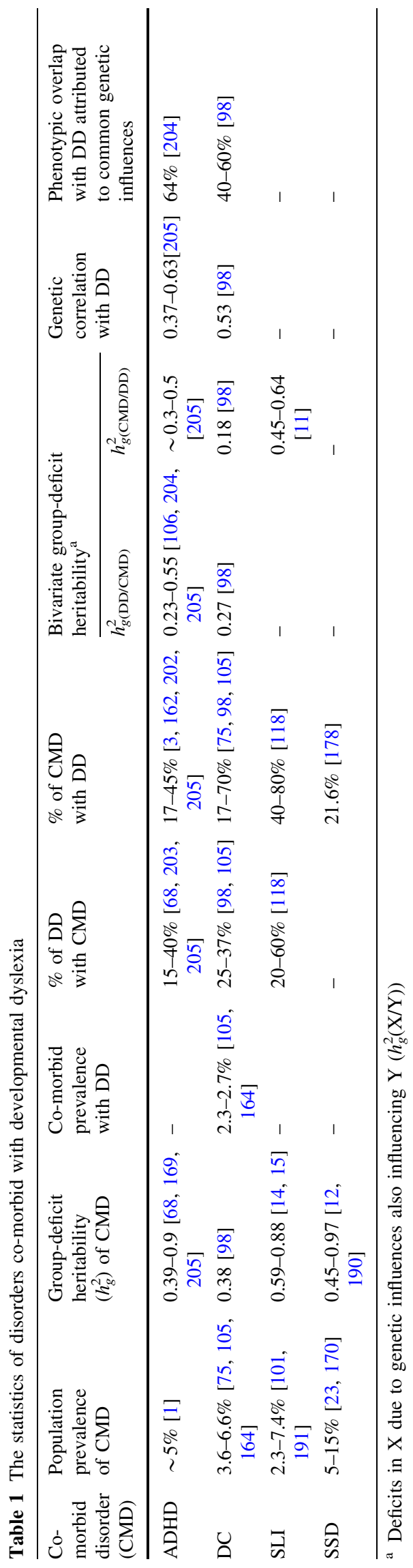

complicates the matter. Indeed, from Table 1, it can be seen that there are shared genetic influences affecting both DD and the co-morbid disorders. Concentrating efforts on homogenous samples affected by DD alone risks delaying the discovery of genes implicated in this disorder. A better strategy might be to record any co-morbid disorders and then treat them as covariates when analysing a sample of DD individuals. Putting this issue aside for now, genetic studies of DD have been successful in the search for candidate susceptibility genes. On the whole, these studies have made stringent attempts to use homogenous samples affected by DD alone.

Molecular genetic studies for DD susceptibility

Not less than 19 independent linkage studies have been performed in the search for DD susceptibility genes (see Table 2). Eight of these were genome-wide linkage screens [39, 46, 47, 54, 93, 94, 117, 127, 129, 146], whilst the remainder generally targeted loci highlighted by the genome-wide screens. Another two genome-wide linkage screens for general reading and spelling ability have also been performed with samples not specifically selected for DD [5, 163].

At least nine DD susceptibility regions have now been mapped and allocated names from DYX1 to DYX9 successively (see Table 3). Subsequent association studies focussed at these regions have led the way in identifying the underlying candidate genes at most of these regions, with the exception of DYX4,DYX6 and DYX9, where no efforts have yet been reported. A summary now follows the remaining $D Y X \#$ loci where reports exist for the positive identification of candidate DD genes. However, before we begin it should be noted that for the ease of reading, this review does not delve into the different selection criteria or reading-related measures used in each study.

\section{DYX1 on chromosome 15}

The first reported linkage to DD susceptibility anywhere in the genome was to the centromere of chromosome 15 [175]. Unfortunately, subsequent studies were unable to replicate this linkage $[10,54,72,157]$. However, an alternative locus on chromosome 15 , from $15 q 15.1$ to 15q21.3, has instead gained support from five independent DD linkage studies (see Fig. 2) [29, 60, 72, 157, 161, 174]. This locus, DYX1, was made all the more interesting by the discovery of a Finnish family co-segregating a balanced translocations of $15 \mathrm{q} 21-22$, specifically $\mathrm{t}(2 ; 15)(\mathrm{q} 11 ; \mathrm{q} 21)$, with reading problems in four members of a two-generation family [128]. The chromosome 15 breakpoint of this translocation disrupts a gene, now known as dyslexia susceptibility 1 candidate 1 (DYX1C1 [MIM 608706]), 
Table 2 A summary of the different linkage studies for developmental dyslexia

\begin{tabular}{|c|c|c|c|c|c|c|c|c|c|c|c|c|c|c|c|}
\hline \multirow{2}{*}{$\begin{array}{l}\text { Study } \\
\text { no. }\end{array}$} & \multirow{2}{*}{$\begin{array}{l}\text { Sample } \\
\text { no. }\end{array}$} & \multirow{2}{*}{$\begin{array}{l}\text { Sample } \\
\text { origin }\end{array}$} & \multirow{2}{*}{$\begin{array}{l}\text { No. of } \\
\text { families }\end{array}$} & \multirow{2}{*}{$\begin{array}{l}\text { Family } \\
\text { type(s) }\end{array}$} & \multirow[t]{2}{*}{ Loci examined } & \multicolumn{9}{|c|}{$D Y X \#$} & \multirow[t]{2}{*}{ References } \\
\hline & & & & & & 1 & 2 & 3 & 4 & 5 & 6 & 7 & 8 & 9 & \\
\hline 1 & 1 & Finland & 1 & Extended & Genome screen & $x$ & $\times$ & $x$ & $\times$ & $\checkmark$ & $\times$ & $\times$ & $\times$ & $\times$ & {$[78,127]$} \\
\hline 2 & 2 & Finland & 11 & Extended & Genome screen & $x$ & $x$ & $\sim$ & $x$ & $\times$ & $\times$ & $x$ & $\times$ & $\times$ & {$[94,141]$} \\
\hline 3 & 3 & Norway & 1 & Extended & Genome screen & $x$ & $\times$ & $\checkmark$ & $x$ & $x$ & $x$ & $x$ & $\times$ & $?$ & [46-48] \\
\hline 4 & 4 & Dutch & 1 & Extended & Genome screen & $x$ & $x$ & $x$ & $x$ & $x$ & $x$ & $x$ & $x$ & $\checkmark$ & [39] \\
\hline 5 & 5 & Dutch & 67 & $\begin{array}{l}\text { ASP males and } \\
\text { mothers }\end{array}$ & $\mathrm{Xq} 27.2-\mathrm{Xq} 28$ & . & . & . & . & . & . & . & . & $\times$ & [39] \\
\hline 6 & 6 & $\begin{array}{l}87 \% \\
\text { Caucasian }\end{array}$ & $\begin{array}{l}51-52 \\
(+38)\end{array}$ & Nuclear + extended & Genome screen & $\checkmark$ & $x$ & $x$ & $x$ & $x$ & $\times$ & $\times$ & $\times$ & $?$ & $\begin{array}{c}{[29,93,} \\
146]\end{array}$ \\
\hline 7 & 7 & America & $9-19$ & Extended & $\operatorname{chr} 15+6 \mathrm{p} 23-\mathrm{q} 23.1$ & $\checkmark$ & $\boldsymbol{V}$ & . & . & . & . & . & $\times$ & . & $\begin{array}{l}{[25,60,} \\
174-176]\end{array}$ \\
\hline 8 & 8 & America & 9 & Multiplex & Various regions & $x$ & . & . & . & . & . & . & $\checkmark$ & . & {$[144]$} \\
\hline 9 & 9 & America & $\begin{array}{c}50 \rightarrow \\
46\end{array}$ & Nuclear twins & $6 \mathrm{p} 23-\mathrm{q} 23.1$ & . & $\checkmark$ & . & . & . & . & . & . & . & {$[25,26]$} \\
\hline 10 & 10 & America & 79 & Nuclear twins & $6 \mathrm{p} 22.3-6 \mathrm{p} 21.2$ & . & $\checkmark$ & . & . & . & . & . & . & . & {$[65]$} \\
\hline 11 & $9+10$ & US & $\begin{array}{l}119 \\
(104)\end{array}$ & Nuclear twins & Genome screen & $x$ & $\boldsymbol{V}$ & $\checkmark$ & $\times$ & $\checkmark$ & $\boldsymbol{V}$ & $x$ & $\times$ & $\times$ & $[54,57,95])$ \\
\hline 12 & 11 & UK & $82-89$ & Nuclear & Genome screen & $x$ & $\boldsymbol{V}$ & $\checkmark$ & $\times$ & $\sim$ & $\checkmark$ & $\sim$ & $x$ & $\sim$ & $\begin{array}{l}{[54,55,} \\
117]\end{array}$ \\
\hline 13 & 12 & UK & 84 & Nuclear & $18 \mathrm{p} 11.31-18 \mathrm{q} 12.2$ & . & . & . & . & . & $\checkmark$ & . & . & . & {$[54,117]$} \\
\hline 14 & 13 & German & 7 & Multiplex & chr6 and chr15 & $\checkmark$ & $\times$ & . & . & . & . & . & . & . & {$[130,157]$} \\
\hline 15 & 14 & German & 82 & Nuclear & $\begin{array}{l}\text { 18p11.21-18q12.3; 15q13.3- } \\
15 \mathrm{q} 22.2\end{array}$ & $\checkmark$ & . & . & . & . & $\times$ & . & . & . & {$[160,161]$} \\
\hline 16 & 15 & Norway & 1 & Extended & Genome screen & $x$ & $x$ & $x$ & $x$ & $x$ & $x$ & $\times$ & $\times$ & $x$ & [129] \\
\hline 17 & 16 & Canadian & $79-100$ & $\begin{array}{l}46-51 \text { nuclear }+ \\
30-50 \text { extended }\end{array}$ & $\begin{array}{l}\text { 1p34-p36; 2p16.3-2p16.1; } \\
\text { 6p25.1-p21.2; 6p12.1-6q16.1; } \\
\text { 11p15.5-11p15.4 }\end{array}$ & . & $\sim$ & $\checkmark$ & $\checkmark$ & . & . & $\boldsymbol{V}$ & $\boldsymbol{V}$ & . & $\begin{array}{l}{[51,90,} \\
137,139 \\
140,194]\end{array}$ \\
\hline 18 & 17 & America & $6-8$ & Extended & $\begin{array}{l}\text { 1p36-1q23; 6p23-p21.3; } \\
\text { chr15; chr16 }\end{array}$ & $\checkmark$ & $\boldsymbol{V}$ & & . & . & . & . & $\checkmark$ & . & {$[71-74]$} \\
\hline 19 & 18 & Danish & 5 & Backcross families & $\operatorname{chr} 15$ & $x$ & . & . & . & . & . & . & . & . & {$[10]$} \\
\hline 20 & 19 & $?$ & 1 & Extended & Various regions & $x$ & $\times$ & . & . & . & . & . & $\times$ & . & {$[153]$} \\
\hline
\end{tabular}

Table 3 A summary of the $D Y X \#$ loci

\begin{tabular}{|c|c|c|c|c|c|c|c|}
\hline DYX\# & $\begin{array}{l}\text { Chromosome } \\
\text { region }\end{array}$ & MIM & $\begin{array}{l}\text { No. of } \\
\text { positive } \\
\text { studies }^{\text {a }}\end{array}$ & $\begin{array}{l}\text { References } \\
\text { of positive } \\
\text { studies }^{\mathrm{a}}\end{array}$ & $\begin{array}{l}\text { No. of } \\
\text { negative } \\
\text { studies }\end{array}$ & References of negative studies & $\begin{array}{l}\text { Candidate DD } \\
\text { susceptibility } \\
\text { genes }\end{array}$ \\
\hline$D Y X 1$ & $15 q 21$ & 127700 & 6 & $\begin{array}{l}{[29,60,72,116,124,130,} \\
\quad 157,161,174]\end{array}$ & 10 & $\begin{array}{l}{[10,39,47,54,94,117,127,129,144,} \\
153]\end{array}$ & $D Y X 1 C 1$ \\
\hline$D Y X 2$ & $6 \mathrm{p} 22.3-\mathrm{p} 21.3$ & 600202 & 7 & $\begin{array}{l}{[25,26,54,55,65,71-73,95} \\
\quad 117,174,193]\end{array}$ & 9 & $\begin{array}{l}{[29,39,46-48,51,93,94,127,129} \\
\quad 130,140,146,153,157]\end{array}$ & $\begin{array}{r}D C D C 2 \text { and } \\
\text { KIAA0319 }\end{array}$ \\
\hline$D Y X 3$ & 2p16-p15 & 604254 & $4(+1)$ & $\begin{array}{l}{[46-48,54,57,117,139]} \\
\quad(+[94,141])\end{array}$ & 4 & {$[29,39,93,127,129,146]$} & $\begin{array}{l}\text { MRPL19 and } \\
\text { C2ORF3 }\end{array}$ \\
\hline$D Y X 4$ & 6q11.2-q12 & {$[\# 127700]$} & 1 & [137] & 8 & {$[39,47,54,93,94,117,127,129,146]$} & - \\
\hline$D Y X 5$ & $3 p 12-q 13$ & 606896 & $2(+1)$ & {$[54,78,127](+[54,117])$} & 5 & {$[39,47,93,94,129,146]$} & $\mathrm{ROBO}$ \\
\hline$D Y X 6$ & $18 \mathrm{p} 11.2$ & 606616 & 3 & {$[54,117]$} & 7 & {$[29,39,47,93,94,127,129,146,160]$} & - \\
\hline$D Y X 7$ & $11 \mathrm{p} 15.5$ & {$[\# 127700]$} & $1(+1)$ & {$[90](+[54,117])$} & 7 & {$[39,47,54,93,94,127,129,146]$} & - \\
\hline$D Y X 8$ & 1p36-p34 & 608995 & 3 & {$[74,144,194]$} & 9 & $\begin{array}{l}{[39,46-48,54,93,94,117,127,129} \\
\quad 146,153]\end{array}$ & KIAA0319L \\
\hline$D Y X 9$ & Xq27.2-q28 & 300509 & $1(+1)$ & [39] $(+[54])$ & 5 & {$[39,54,94,127,129]$} & - \\
\hline
\end{tabular}

${ }^{a}$ Positive studies, and their references, in brackets indicate linkages close to the DYX\# loci 


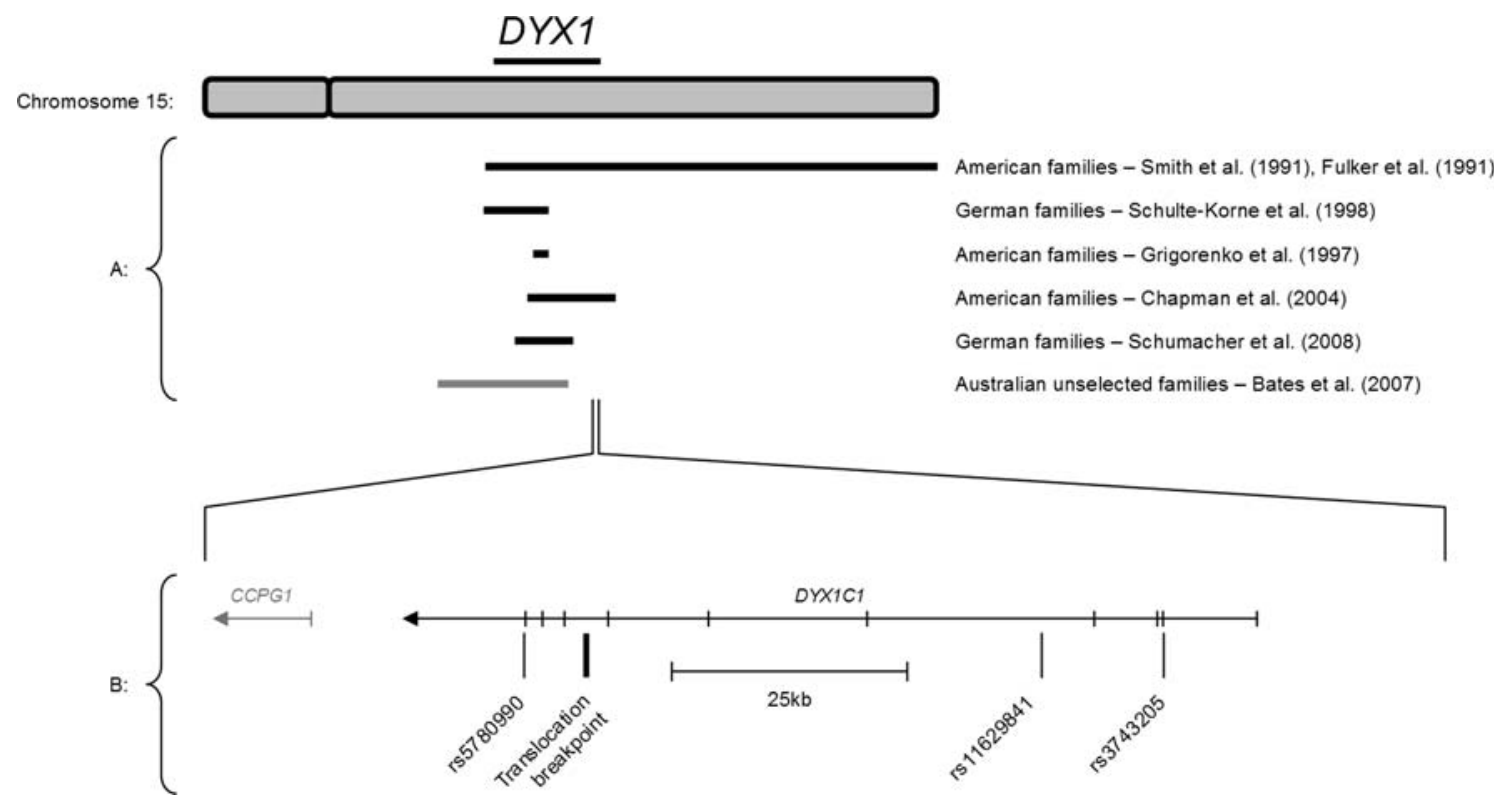

Fig. 2 The DYX1 locus on chromosome 15. a Black horizontal lines are linkage reports for DD from independent samples. Box with diagonal lines indicates a translocation. $\mathbf{b}$ Genes that have been tested

between exons 8 and 9 [184]. A subsequent association study of DYX1C1 performed with a Finnish sample revealed an increased frequency of two alleles in DD individuals; $-3 \mathrm{~A}$ from the SNP rs3743205 $(-3 \mathrm{G}>\mathrm{A})$ and 1249T from rs57809907 (1249G $>$ T) [184]. A haplotype of these two alleles, $-3 \mathrm{~A}: 1249 \mathrm{~T}$, also associated with DD. A separate sample of Finnish cases and controls again revealed a significant association with these same alleles [184]. The allele $-3 \mathrm{~A}$ disrupts a putative promoter-binding site and $1249 \mathrm{~T}$ is a nonsense mutation resulting in the loss of ten amino acids from the N-terminus of the full-length protein. Hence, both SNPs made attractive functional mutations with regard to DD.

Efforts to replicate these associations have produced mixed results and interpretations (see Table 4). Ten independent studies have tested rs3743205, rs57809907 and numerous other SNPs within DYX1C1 for association with DD or reading-related measures $[6,7,18,32,37,113,114$, $122,154,184,200]$. Four of these studies provide no support for either rs3743205 or rs57809907 [6, 7, 32, 122], whilst the others produce conflicting results $[18,37,113,154,184$, 200]. Specifically, two studies lend support to $-3 \mathrm{~A}$ and 1249T, and four studies to $-3 \mathrm{G}$ and $1249 \mathrm{G}$. The associations from the studies are mostly nominally significant and may result from multiple testing of numerous phenotypes. Four of these studies also report associations with other DYX1C1 variants, but none are replicated as yet. Two further studies have tested autism and ADHD samples for association with rs3743205 and rs57809907, but only yield limited support for -3G:1249G and ADHD [201, 202, 210]. for association. Interesting SNPs, deletions or translocation breakpoints are highlighted

Therefore, it is unlikely, but not impossible, that rs3743205 and rs57809907 are causative for DD. An alternative explanation is that they are in linkage disequilibrium with a causative genetic variant. This idea is supported by the fact that the four DD samples yielding association between the alleles $-3 \mathrm{G}$ and $1249 \mathrm{G}$ are of central European descent, whilst the others supporting $-3 \mathrm{~A}$ and $1249 \mathrm{~T}$ are of Finnish and Italian descent. Hence, the causative genetic variant could be present on one haplotypic background of central European descent, and on a different haplotypic background in other populations. Alternatively, different causative mutations might exist between different populations.

\section{DYX2 on chromosome 6}

A DD susceptibility locus on the short arm of chromosome 6, known as $D Y X 2$, has been reported by at least five independent studies (see Fig. 3) [25, 54, 55, 65, 71-73, 95, 174]. DYX2 is located at 6p22.3-p21.3 and spans over $15 \mathrm{Mb}$. It was the first locus to be positively replicated for DD susceptibility. Possibly for this reason, DYX2 became a focal point for subsequent association studies employing extensive high-throughput genotyping methods (Table 5). Many genetic variants have been tested, including microsatellites and SNPs, and lots of sporadic associations have been observed to a range of genes. However, from all these studies of $D Y X 2$, there are two genes that stand out: KIAA0319 and DCDC2. These genes are just $150 \mathrm{~kb}$ from one another on $6 \mathrm{p} 22.2$. 
Table 4 Reported associations of $D Y X 1 C 1$ at $D Y X 1$

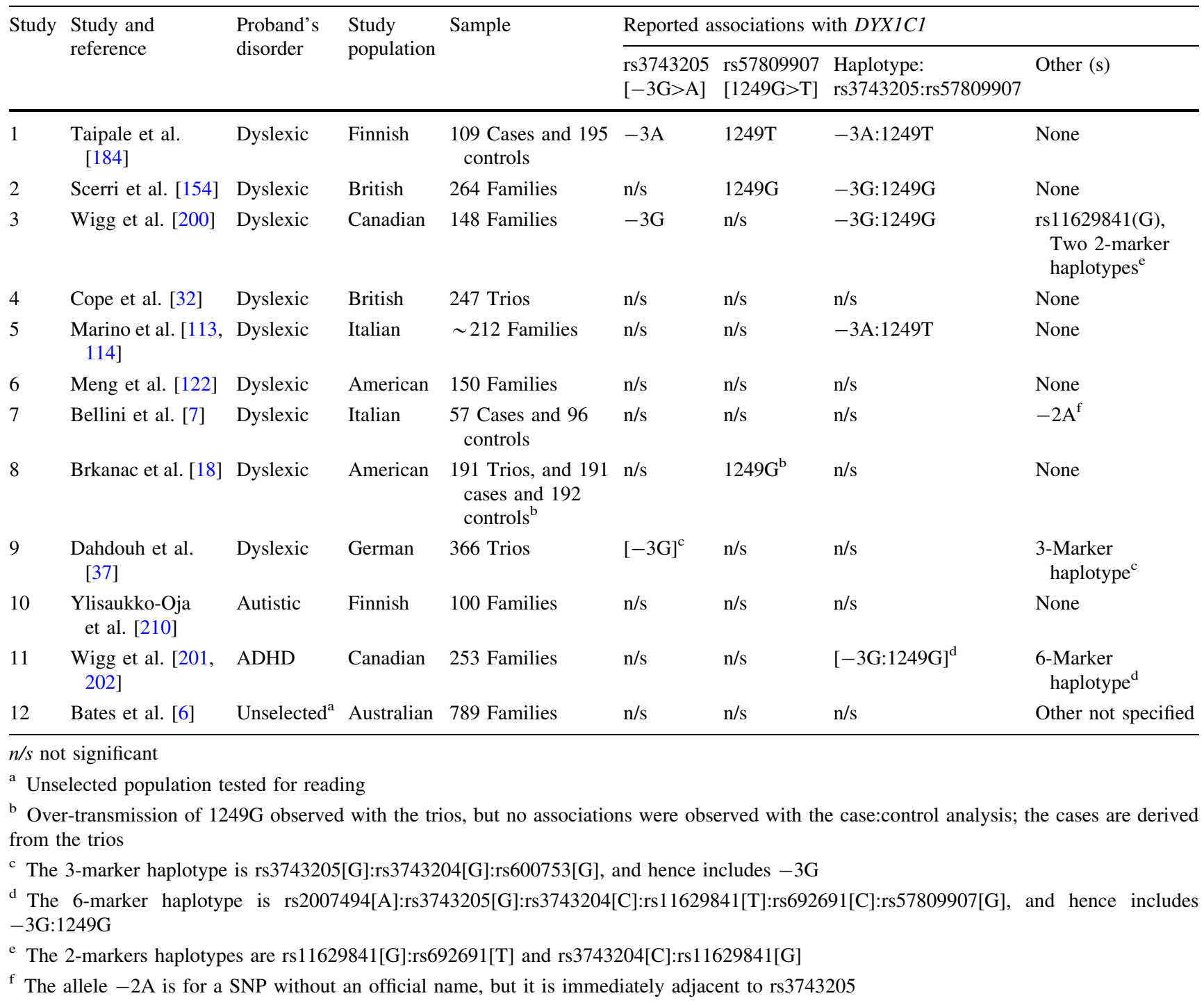

Association with KIAA0319 was first identified in a study of $D X Y 2$ using samples from the Colorado Learning Disabilities Research Center (CLDRC) [95]. In this study, association was observed to a microsatellite marker known as JA04 that resides within the first exon of KIAA0319. Although association with JA04 has never been replicated, four of the five independent DD studies to have tested KIAA0319 do find association with other markers [18, 31, 40, 44, 59, 80, 95, 121, 158]. Although these associated markers are distributed across the entire $102 \mathrm{~kb}$ length of $K I A A 0319$, there is a tendency for the most significant associations to cluster around the first intron and predicted promoter region of this gene. Four markers, namely rs4504469, rs6935076, rs2038137 and rs2143340 (actually located in the adjacent gene called "TRAF and TNF receptor associated protein" (TTRAP [MIM 605764])), have each been robustly associated in at least two independent samples. Furthermore, a specific risk-haplotype composed of rs4504469, rs2038137 and rs2143340 has been shown to associate with DD in three independent samples. This risk-haplotype has also been tested and associated with a range of reading-related measures in two large unselected samples; approximately 6,000 children from the Avon Longitudinal Study of Parents and Children (ALSPAC) [134] and a sample of 440 twins collected from Queensland, Australia [110]. Disconcertingly, the haplotype within KIAA0319 was actually associated with better reading scores in the Australian twin sample. The two likely explanations for this are a type I error or a consequence of the sample being ethnically heterogeneousonly $\sim 82 \%$ of the sample was reportedly of Anglo-Celtic origin [110]. Nevertheless, functional studies have been performed with this risk-haplotype, and an elegant experiment has associated it with a reduction in the expression of 


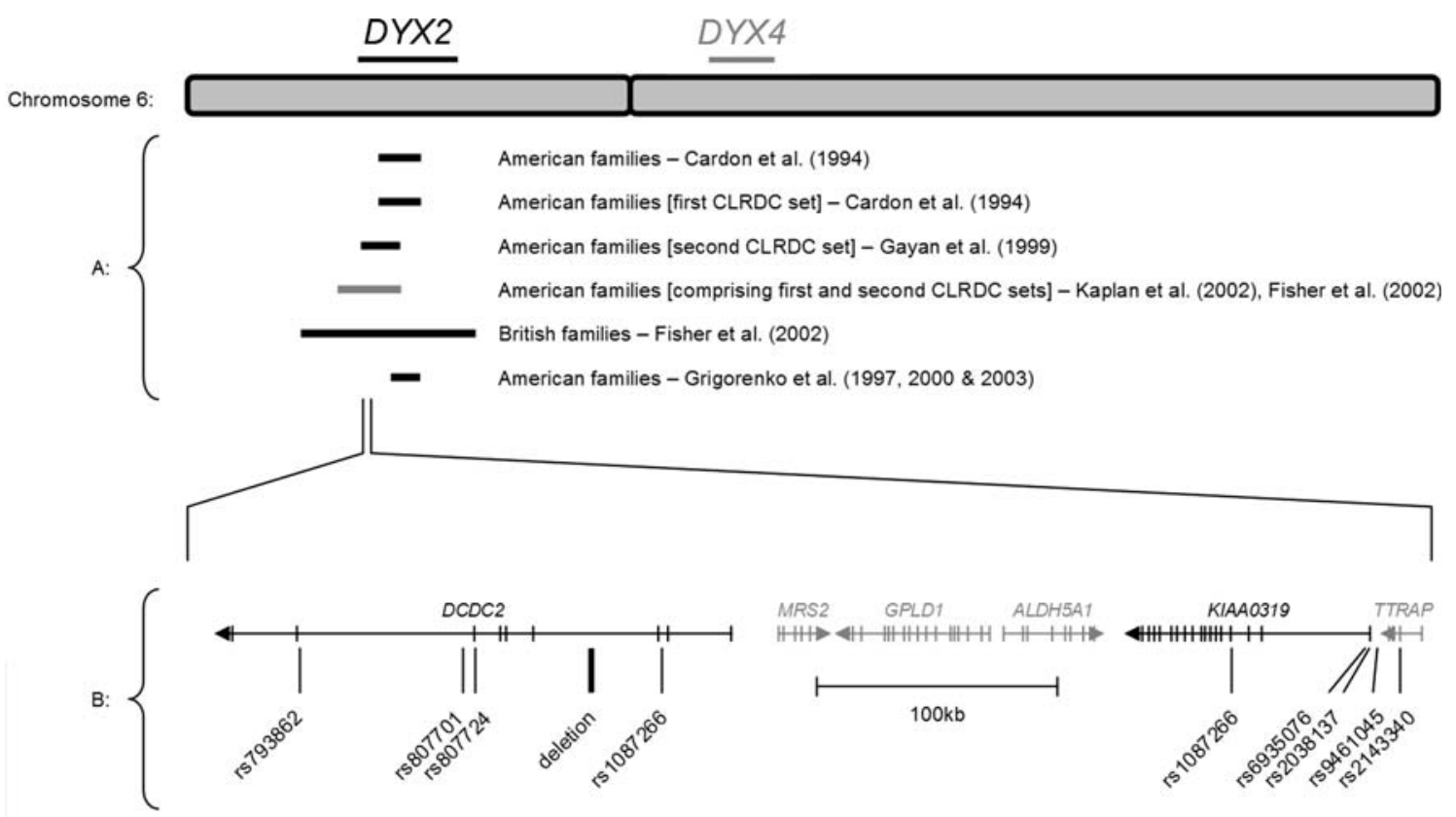

Fig. 3 The DYX2 locus on chromosome 6. a Black horizontal lines are linkage reports for DD from independent samples. Box with diagonal lines indicates a translocation. $\mathbf{b}$ Genes that have been tested for association. Interesting SNPs, deletions or translocation breakpoints are highlighted

appears to be with the minor allele $[35,40,121,158]$, in the remaining British sample, it is with the major allele [80]. However, the association observed in this British sample is modest ( $P$ values from 0.02 to 0.04 ), suggesting it may be a type I error. Lastly, an independent study has examined the effect of the $D C D C 2$ deletion on the brain morphology of healthy samples (not selected for DD). A significant increase in grey matter in regions of the brain involved in reading was observed in individuals heterozygous for the deletion (individuals homozygous for the deletions were too infrequent and so not tested) [120].

For both KIAA0319 and DCDC2, independent studies have observed that the significance of the associations within these genes increase on selecting a sub-set of samples containing the more severe cases of DD [59, 80, 158]. On the other hand, it is interesting to note that markers within these genes have also been associated with general reading ability within two unselected populations [6, 110, 134]. One possible interpretation is that variants within both genes can influence the development of reading ability, but that there are also specific functional variants within these genes that can cause DD.

Finally, two independent analysis have tested for an interaction been the markers of DCDC2 and KIAA0319 [80, 111]. Both studies find an interaction with a single SNP (rs761100) within KIAA0319 and either rs793862 alone [80], or the haplotype it forms with rs807701 [111], within $D C D C 2$. Further work is required to determine 


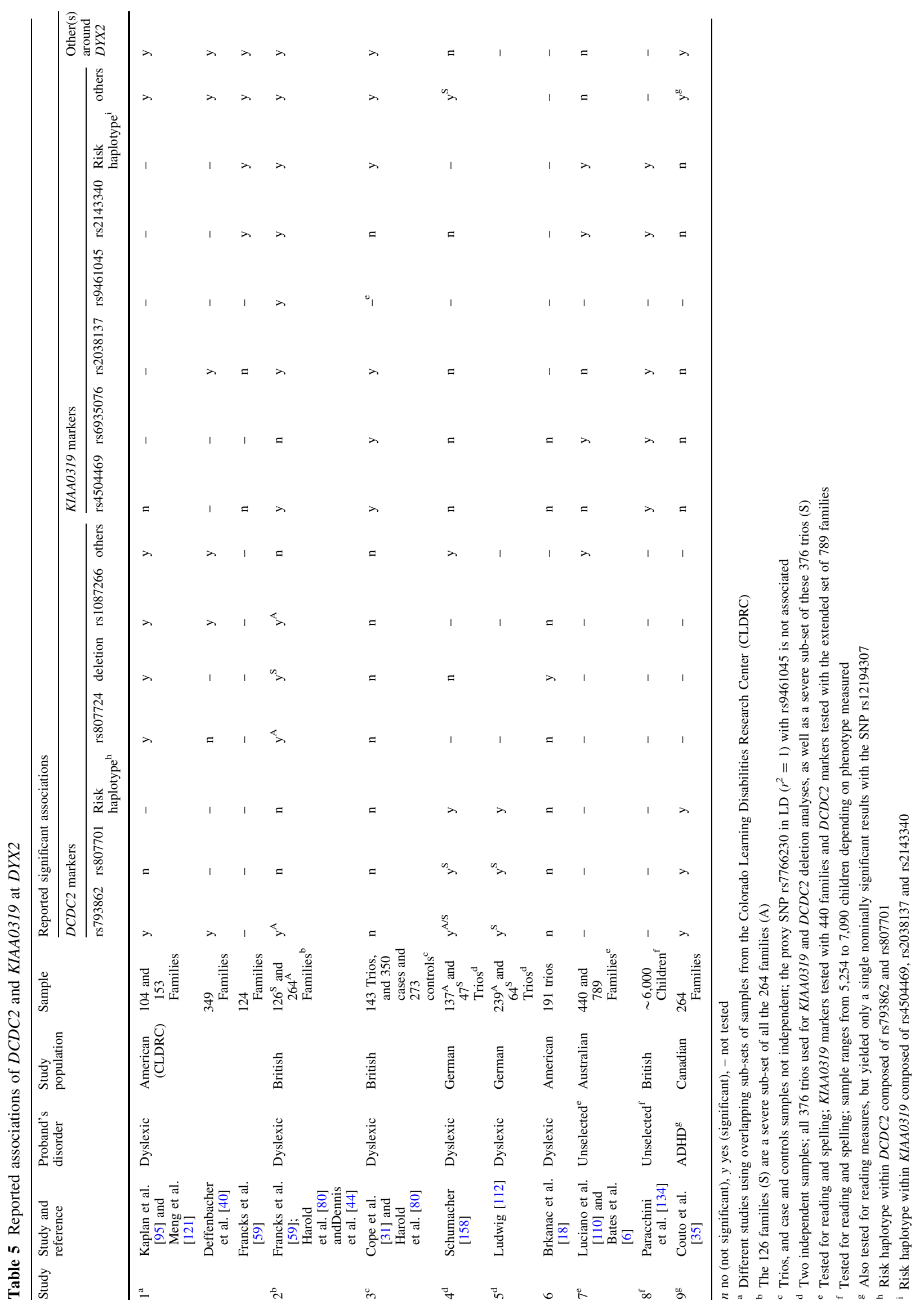


whether the interactions are between the same alleles in these two studies.

\section{DYX3 on chromosome 2}

A locus for DD susceptibility on chromosome 2 was first observed in one of the earliest genome-wide linkage scans for this disorder, using a large pedigree of Norwegian descent [47]. DYX2 is located on the short arm of chromosome 2, at 2p15-16. Linkage to DD has since been observed to $D Y X 2$ in at least three independent studies of British, American and Canadian families (see Fig. 4) [54, 139]. A further study has identified a locus close to $D Y X 2$, at $2 \mathrm{p} 11$, reportedly linked to DD in a sample of Finnish families [94]. From the few early association studies to investigate this region, negative findings were reported for a very small number of SNPs in the gene tachykinin receptor 1 (TACR1 [MIM 162323]) within the Finnish families [141], and also the two genes "sema domain, immunoglobulin domain, transmembrane domain and short cytoplasmic domain, (semaphorin) 4F" (SEMA4F [MIM 603706]) and orthodenticle homeobox 1 (OTX1 [MIM 600036]) in the American families [57].

Subsequently, the Finnish locus has been re-investigated in a high-density SNP association study covering $\sim 5 \mathrm{Mb}$ of genomic sequence [2]. On this occasion, association was observed in an overlapping region in two independent samples of Finnish and German descent. In both samples, a range of haplotypes were found associated with DD. Common to several of these risk-haplotypes were the two SNPs rs917235 and rs714939, and importantly in both the Finnish and German samples an allele $G$ at both rs917235 and rs714939 was over-transmitted to the DD samples.
Flanking these two SNPs are three genes; "family with sequence similarity 176, member A" (FAM176A), mitochondrial ribosomal protein L19 (MRPL19 [MIM 611832]) and chromosome 2 open reading frame 3 (C2ORF3 [MIM 189901]). A reduction in the expression of both MRPL19 and $C 2 O R F 3$ was subsequently observed from chromosomes carrying derivates of the risk-haplotype; specifically, from chromosomes carrying both rs917235[G] and rs714939[G] [2].

\section{DYX5 on chromosome 3}

Linkage to the peri-centromeric region of chromosome 3 has been observed for DD susceptibility in three independent genome-wide screens (see Fig. 5). First, linkage was reported in a Finnish family spanning the centromere of chromosome 3 from 3 p12 to q13 [127]. Within this four generation family, it was deduced that 19 out of 21 affected individuals carried a common haplotype identical-by-descent that was about $35 \mathrm{Mb}$ in length. Linkage to DD was subsequently reported at 3 p13 in a British sample and 3q13 in an American sample [54]. In addition, linkage for reading ability at this peri-centromeric region was also observed in a sample of American families ascertained for SSD [178]. Specifically, linkage for the reading measures was observed at 3 p12 and from 3 p12 to $q 12$ for other language-related measures also tested [178].

The first DD association study to examine this region produced negative results in a sample of Italian families for the gene dopamine receptor D3 (DRD3 [MIM 126451]) located at 3q13 [115].

Subsequently, the gene "roundabout, axon guidance receptor, homolog 1 (Drosophila)" (ROBO1 [MIM

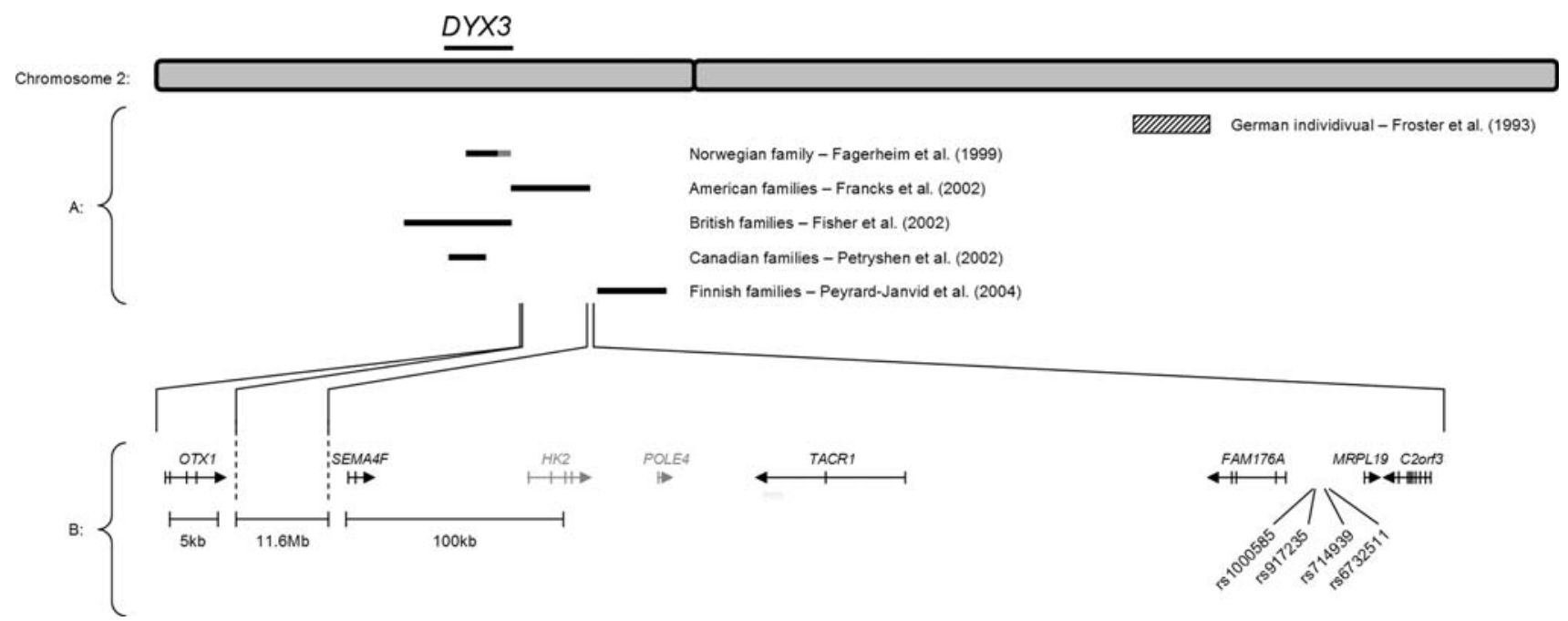

Fig. 4 The DYX3 locus on chromosome 2. a Black horizontal lines are linkage reports for DD from independent samples. Box with diagonal lines indicates a translocation. $\mathbf{b}$ Genes that have been tested for association. Interesting SNPs, deletions or translocation breakpoints are highlighted 

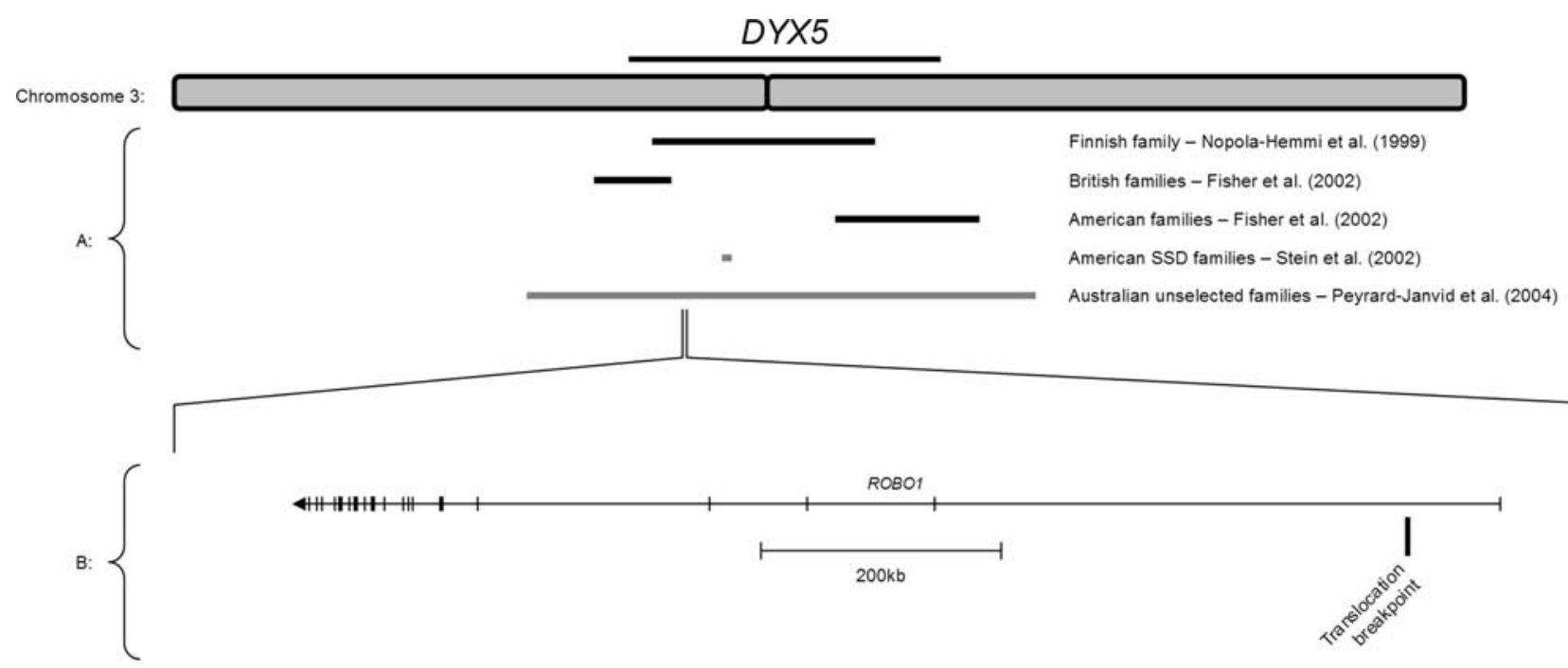

Fig. 5 The DYX5 locus on chromosome 3. a Black horizontal lines are linkage reports for DD from independent samples. Box with diagonal lines indicates a translocation. $\mathbf{b}$ Genes that have been tested

602430]) has been identified as a likely candidate gene for DD susceptibility. The primary evidence comes from an individual carrying a translocation involving $D Y X 5$, specifically $\mathrm{t}(3 ; 8)(\mathrm{p} 12 ; \mathrm{q} 11)$, and who is also affected with DD [78]. The chromosome 3 breakpoint of this translocation was identified between exons 1 and 2 of $R O B O 1$. The 35-Mb haplotype co-segregating with DD in the large Finnish family includes $R O B O 1$, and expression of $R O B O 1$ from this specific haplotype was shown to be significantly reduced, either partially or completely [78]. $R O B O 1$ is nearly $1 \mathrm{Mb}$ in length and contains thousands of SNPs. A limited assessment of some of these SNPs in independent samples could not yield evidence for an association with DD [78], which may be explained by a different diagnostic criteria in the replication sample.

\section{DYX7 on chromosome 11}

Just two studies report the linkage of a DD susceptibility locus to chromosome 11 . Both studies report linkage at 11p15; specifically at $11 \mathrm{p} 15.4$ in a British sample [54] and 11 p15.5 in a Canadian sample [90]. The linkage observed in the latter study appears to peak in a region containing the gene dopamine receptor D4 (DRD4 [MIM 126452]). However, analysis of DRD4 in the Canadian sample and also in an independent sample of Italian families has found no evidence of an association with DD [90, 115].

\section{DYX8 on chromosome 1}

Linkage to DD susceptibility has been reported at chromosome 1 in three independent studies (see Fig. 6) [74, 144, 194]. Up-to-date genetic maps reveal a consensus for association. Interesting SNPs, deletions or translocation breakpoints are highlighted

region of linkage at 1p36 in all three studies [74, 144, 194], but there is also evidence for linkage at 1p34-35 from two of these studies as well [74, 194]. Located at 1p34.3 is the gene KIAA0319-like (KIAA0319L) which has a highprotein sequence identity to KIAA0319. KIAA0319L is therefore a natural target for association studies given its proximity to $D Y X 8$ and homology to KIAA0319. However, just a single study has reported an investigation of KIAA0319L in a sample of Canadian families [34]. Of the handful of SNPs to have been tested, modest association with DD was observed in just one SNP and a haplotype derived from that SNP [34].

\section{Other candidate DD gene studies}

Other loci have received attention from DD linkage and association studies, despite limited evidence from linkage studies. For example, dopamine receptor D1 (DRD1 [MIM 126449]) at 5q35, dopamine receptor D2 (DRD2 [MIM 126450]) at 11q23, dopamine receptor D5 (DRD5 [MIM 126453]) at 4p16 and "solute carrier family 6 (neurotransmitter transporter, dopamine), member 3" (SLC6A3 [MIM 1406597]) at 5p15 have all been investigated, but show modest or no linkage or association with DD susceptibility [109, 115, 138].

A single family co-segregating dyslexia and a telomeric deletion of at least $176 \mathrm{~kb}$ from the q-arm of chromosome 21 in four out of nine family members has also been reported [142]. This region contains four genes that may be variably affected by the deletion; pericentrin (PCNT [MIM 605925]), DIP2 disco-interacting protein 2 homolog A (Drosophila) (DIP2A [MIM 607711]), S100 calciumbinding protein B (S100B [MIM 176990]), and protein 


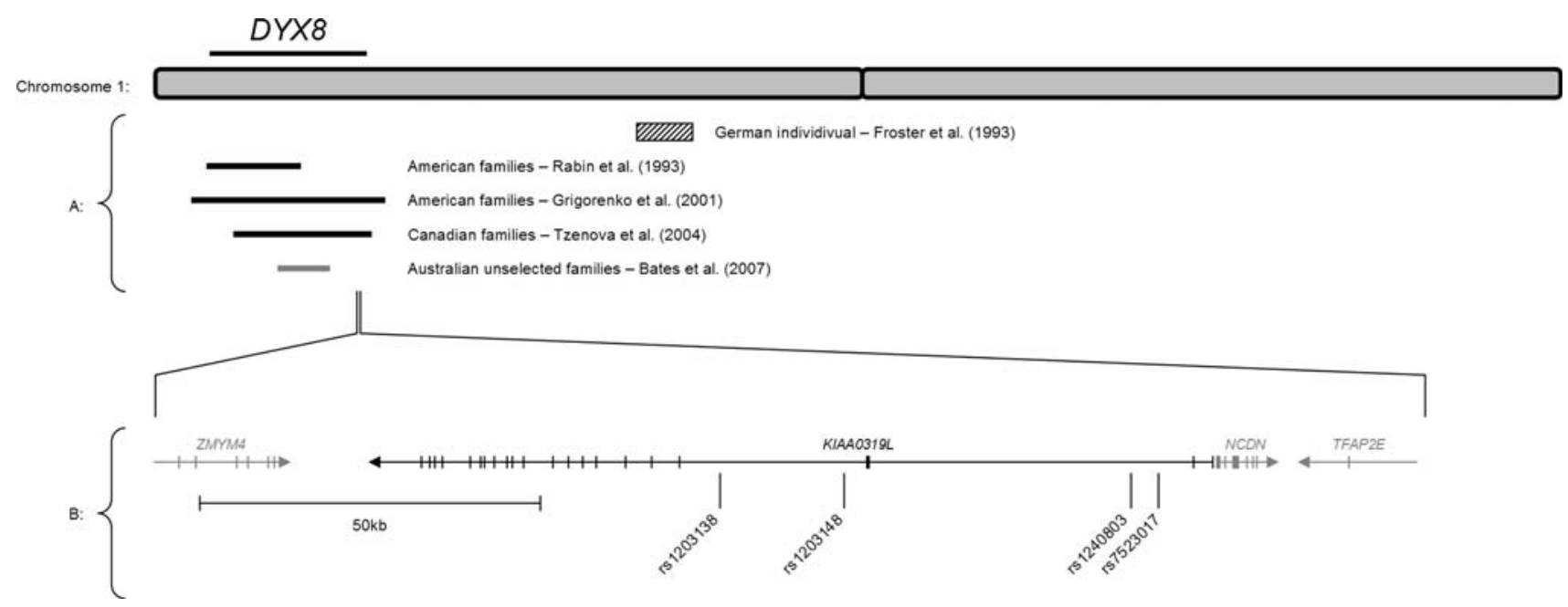

Fig. 6 The DYX8 locus on chromosome 1. a Black horizontal lines are linkage reports for DD from independent samples. Box with diagonal lines indicates a translocation. $\mathbf{b}$ Genes that have been tested

arginine methyltransferase 2 (PRMT2 [MIM 601961]). The authors suggest $D I P 2 A$ as the most likely candidate DD susceptibility gene of the four because of its function in the regulation of neuronal connectivity [142]. However, this inference of $D I P 2 A$ s function is incorrect as the authors have inadvertently identified $D I P 2 A$ as "DLX interacting protein 2 (DIP2)" which is an alternatively spliced form of glutamate receptor interacting protein 1 (GRIP1 [MIM 604597]) [211], rather than "DIP2 disco-interacting protein 2 homolog A (Drosophila)". DIP2A may still be involved in neuronal connectivity although as shown by mutation experiments of the disconnected gene (disco) in Drosophila $[125,180]$. S10OB is also an attractive candidate for DD susceptibility as SNPs within this gene have been associated with low cognitive ability in the elderly [100], schizophrenia [107] and bipolar disorder [149]. However, it is impossible to assess the influence of any of the four genes with respect to DD without evidence from linkage or association studies from independent samples.

Characterisation of the DD susceptibility genes

As described, seven candidate DD genes have been identified with supporting evidence from two or more independent DD studies; DYXIC1 at DYX1, KIAA0319 and $D C D C 2$ at $D Y X 2, M R P L 19$ and $C 2$ orf 3 at $D Y X 3, R O B O 1$ at DYX5 and KIAA0319L at DYX8. Some evidence for other genes has been identified from a single family cosegregating DD and a deletion on chromosome 21; PCNT, DIP2A, SIOOB and PRMT2.

Functional characterisation of these genes has revealed that many of them have important roles in the brain, often during embryonic development. In particular, DYX1C1, for association. Interesting SNPs, deletions or translocation breakpoints are highlighted

$D C D C 2, K I A A 0319, S 100 B$ and $R O B O 1$ have all been implicated in neuronal migration $[20,121,135,150,189$, 198, 199]. ROBOI and DIP2A may also be involved in axon guidance and neural development $[97,125,180]$. This adds further weight to their involvement in DD because disruptions of these genes could result in the abnormalities observed from the postmortem examinations of DD brains, such as the focal architectonic dysplasias and neuronal ectopias which result from disruptions in neuronal migration [61, 63, 92]. Indeed, disruption of Dyxlc1 activity in adult rodent brains revealed hippocampal dysplasias and molecular layer ectopias similar in appearance to those reportedly seen in the postmortem DD brains [150]. Behavioural studies of rodents with disruptions of Dyxlcl activity revealed deficits in discerning auditory stimuli and spatial learning, particularly in the rodents displaying hippocampal heterotopias [189]; auditory detection deficits are good behavioural markers for SLI and DD $[8,185]$, and the hippocampus is important in spatial and working memory [9, 22, 132]. However, only a sub-set of DD individuals actually presents deficits in these phenotypes, and these deficits are not part of the definition of DD. Hence, it is possible that the effect of disrupting DYXIC1 activity is to produce a general or wide-ranging cognitive deficit that would not be restricted to just reading ability in humans.

Nevertheless, disrupting the activity of these candidate genes in rodents has shown that they may produce anatomical phenotypes similar to those observed in human DD brains. However, it should be noted that only a small number of human DD brains have actually been examined anatomically. Furthermore, the specificity of the anatomical effects observed in rodents may not correlate precisely 
with regions affected by autopsies or functional imaging studies of DD brains. Indeed, the disruption of Dyxlcl produced quite general effects, including regions of the brain not implicated in DD.

Whole-genome association studies

Although there have been no published whole-genomewide association screens for DD specifically, there have been two other studies of reading ability. The first has used several thousand samples from the Twins Early Development Study (TEDS) [131], and compared genotypes from pooled samples of high and low reading ability individuals [119]. The second involved 705 stroke- and dementia-free individuals from the Framingham study tested for a range of cognitive measures [163]. Both studies genotyped their samples on the $100 \mathrm{~K}$ Affymetrix microarrays. Neither study found associations within any of the candidate DD genes discussed in this review, although both studies did find a variety of signals in the broader linkage regions of the DYX\# loci. Lastly, we are part of a large consortium known as NeuroDys (http://www.neurodys.com) that is in the latter stages of a whole-genome-wide association screen for DD. We have individually genotyped 600 samples with DD on either the 350 or $550 \mathrm{~K}$ Illumina microarrays, and several hundreds more on the $1 \mathrm{M}$ Illumina chip with a pooled sample approach. Integrating individual data from intensive neuropsychogical testing, brain imaging and electrophysiological studies, the significance of different endophenotypes will be investigated. The overall goal of this project is to understand the biological basis of dyslexia through investigating the correlations between candidate genes and brain functions that are found to be relevant for learning to read and to spell like speech perception and grapheme-phoneme association.

\section{Summary and outlook}

Numerous candidate DD susceptibility genes have now been identified at a variety of loci; $D Y X 1 C 1$ at $D Y X 1$ [184], KIAA0319 and DCDC2 at DYX2 [31, 59, 80, 121, 135, 158], MRPL19 and C2ORF3 close to DYX3 [2], ROBO1 at DYX5 [78] and KIAA0319L at DYX8 [34]. The evidence for each of these genes has been acquired from cytogenetic, linkage, association and biological studies.

Upon discovering genes for DD susceptibility and their underlying causal variants, it is envisaged that 1-day young people may be screened for their potential risk in developing DD. Appropriate action may then be taken to reduce this risk by providing tailored tuition governed by their underlying genetic makeup. There may even be the potential for the design of drugs to be prescribed in the most extreme of cases. Finally, the discovery of these genes will allow us to learn more about human cognition and our unique abilities to communicate with one another.

To achieve these aims, the subsequent steps of molecular genetic work are genome-wide association studies based on the samples of several thousand of dyslexic individuals. This goal can be reached by joint research initiatives such as the EU project NeuroDys that currently has access to the DNA from two thousand dyslexic children from eight EU member states. Essential for this research strategy is that the dyslexic individuals are phenotypically well characterised. Based on the gene-gene interaction studies, the contribution of a single susceptibility genes will be better understood. Moreover, the investigation of copy number variants in dyslexic samples might help in detecting clinically relevant variations that contribute to the development of dyslexia.

\section{References}

1. American Psychiatric Association (1994) American Psychiatric Association: Task force on DSM-IV. Diagnostic and statistical manual of mental disorders: DSM-IV, 4th edn. American Pyschiatric Association, Washington, DC

2. Anthoni H, Zucchelli M, Matsson $\mathrm{H}$ et al (2007) A locus on 2 p12 containing the co-regulated MRPL19 and C2ORF3 genes is associated to dyslexia. Hum Mol Genet 16(6):667-677

3. August GJ, Garfinkel BD (1990) Comorbidity of ADHD and reading disability among clinic-referred children. J Abnorm Child Psychol 18(1):29-45

4. Bakwin H (1973) Reading disability in twins. Dev Med Child Neurol 15(2):184-187

5. Bates TC, Luciano M, Castles A et al (2007) Replication of reported linkages for dyslexia and spelling and suggestive evidence for novel regions on chromosomes 4 and 17. Eur J Hum Genet 15(2):194-203

6. Bates TC, Luciano M, Lind PA et al (2007) Genetic influences on dyslexia: support for DYX1C1 and DCDC2. World Congress of Psychiatric Genetics, New York City

7. Bellini G, Bravaccio C, Calamoneri F et al (2005) No evidence for association between dyslexia and DYX1C1 functional variants in a group of children and adolescents from Southern Italy. J Mol Neurosci 27(3):311-314

8. Benasich AA, Tallal P (2002) Infant discrimination of rapid auditory cues predicts later language impairment. Behav Brain Res 136(1):31-49

9. Bird CM, Burgess N (2008) The hippocampus and memory: insights from spatial processing. Nat Rev Neurosci 9(3):182194

10. Bisgaard ML, Eiberg H, Moller N et al (1987) Dyslexia and chromosome 15 heteromorphism: negative lod score in a Danish material. Clin Genet 32(2):118-119

11. Bishop DV (2001) Genetic influences on language impairment and literacy problems in children: same or different? J Child Psychol Psychiatry 42(2):189-198

12. Bishop DV (2002) Motor immaturity and specific speech and language impairment: evidence for a common genetic basis. Am J Med Genet 114(1):56-63 
13. Bishop DV, Adams C (1990) A prospective study of the relationship between specific language impairment, phonological disorders and reading retardation. J Child Psychol Psychiatry 31(7):1027-1050

14. Bishop DVM (2005) DeFries-Fulker analysis of twin data with skewed distributions: cautions and recommendations from a study of children's use of verb inflections. Behav Genet 35(4):479-490

15. Bishop DVM, Adams CV, Norbury CF (2006) Distinct genetic influences on grammar and phonological short-term memory deficits: evidence from 6-year-old twins. Genes Brain Behav 5(2):158-169

16. Boets B, De Smedt B, Wouters $\mathrm{J}$ et al (2007) No relation between 2D: 4D fetal testosterone marker and dyslexia. Neuroreport 18(14):1487-1491

17. Brady SA, Shankweiler DP (1991) Phonological processes in literacy. Lawrence Erlbaum, Hillsdale

18. Brkanac Z, Chapman NH, Matsushita MM et al (2007) Evaluation of candidate genes for DYX1 and DYX2 in families with dyslexia. Am J Med Genet B Neuropsychiatr Genet 144(4):556560

19. Brown WE, Eliez S, Menon V et al (2001) Preliminary evidence of widespread morphological variations of the brain in dyslexia. Neurology 56(6):781-783

20. Brozzi F, Arcuri C, Giambanco I et al (2009) S100B protein regulates astrocyte shape and migration via interaction with $\mathrm{Src}$ kinase: implications for astrocyte development, activation, and tumor growth. J Biol Chem 284(13):8797-8811

21. Brunswick N, McCrory E, Price CJ et al (1999) Explicit and implicit processing of words and pseudowords by adult developmental dyslexics: a search for Wernicke's Wortschatz? Brain 122(Pt 10):1901-1917

22. Burgess N, Maguire EA, O'Keefe J (2002) The human hippocampus and spatial and episodic memory. Neuron 35(4):625641

23. Campbell TF, Dollaghan CA, Rockette HE et al (2003) Risk factors for speech delay of unknown origin in 3-year-old children. Child Dev 74(2):346-357

24. Capel ID, Pinnock MH, Dorrell HM et al (1981) Comparison of concentrations of some trace, bulk, and toxic metals in the hair of normal and dyslexic children. Clin Chem 27(6):879-881

25. Cardon LR, Smith SD, Fulker DW et al (1994) Quantitative trait locus for reading disability on chromosome 6. Science 266(5183):276-279

26. Cardon LR, Smith SD, Fulker DW et al (1995) Quantitative trait locus for reading disability: correction. Science 268(5217):1553

27. Castles A, Datta H, Gayan J et al (1999) Varieties of developmental reading disorder: genetic and environmental influences. J Exp Child Psychol 72(2):73-94

28. Chan DW, Ho CSH, Tsang SM et al (2007) Prevalence, gender ratio and gender differences in reading-related cognitive abilities among Chinese children with dyslexia in Hong Kong. Educ Stud 33(2):249-265

29. Chapman NH, Igo RP, Thomson JB et al (2004) Linkage analyses of four regions previously implicated in dyslexia: confirmation of a locus on chromosome 15q. Am J Med Genet B Neuropsychiatr Genet 131B(1):67-75

30. Chiu MM, McBride-Chang C (2006) Gender, context, and reading: a comparison of students in 43 countries. Sci Stud Read 10(4):331-362

31. Cope N, Harold D, Hill G et al (2005) Strong evidence that KIAA0319 on chromosome $6 p$ is a susceptibility gene for developmental dyslexia. Am J Hum Genet 76(4):581-591

32. Cope NA, Hill G, van den Bree M et al (2005) No support for association between dyslexia susceptibility 1 candidate 1 and developmental dyslexia. Mol Psychiatry 10(3):237-238
33. Corina DP, Richards TL, Serafini S et al (2001) fMRI auditory language differences between dyslexic and able reading children. Neuroreport 12(6):1195-1201

34. Couto JM, Gomez L, Wigg K et al (2008) The KIAA0319-like (KIAA0319L) gene on chromosome 1p34 as a candidate for reading disabilities. J Neurogenet 22(4):295-313

35. Couto JM, Gomez L, Wigg K et al (2009) Association of attention-deficit/hyperactivity disorder with a candidate region for reading disabilities on chromosome 6p. Biol Psychiatry 66(4):368-375

36. Cyhlarova E, Bell JG, Dick JR et al (2007) Membrane fatty acids, reading and spelling in dyslexic and non-dyslexic adults. Eur Neuropsychopharmacol 17(2):116-121

37. Dahdouh F, Anthoni H, Tapia-Paez I et al (2009) Further evidence for DYX1C1 as a susceptibility factor for dyslexia. Psychiatr Genet 19(2):59-63

38. Davis CJ, Gayan J, Knopik VS et al (2001) Etiology of reading difficulties and rapid naming: the Colorado Twin Study of Reading Disability. Behav Genet 31(6):625-635

39. de Kovel CG, Hol FA, Heister JG et al (2004) Genomewide scan identifies susceptibility locus for dyslexia on Xq27 in an extended Dutch family. J Med Genet 41(9):652-657

40. Deffenbacher KE, Kenyon JB, Hoover DM et al (2004) Refinement of the 6 p21.3 quantitative trait locus influencing dyslexia: linkage and association analyses. Hum Genet 115(2): $128-138$

41. DeFries JC, Alarcón M (1996) Genetics of specific reading disability. Ment Retard Dev Disabil Res Rev 2:39-47

42. DeFries JC, Fulker DW, LaBuda MC (1987) Evidence for a genetic aetiology in reading disability of twins. Nature 329(6139):537-539

43. Demonet JF, Taylor MJ, Chaix Y (2004) Developmental dyslexia. Lancet 363(9419):1451-1460

44. Dennis MY, Paracchini S, Scerri TS et al (2009) A common variant associated with dyslexia reduces expression of the KIAA0319 gene. PLoS Genet 5(3):e1000436

45. Eckert MA, Leonard CM, Richards TL et al (2003) Anatomical correlates of dyslexia: frontal and cerebellar findings. Brain 126(Pt 2):482-494

46. Fagerheim T, Raeymaekers P, Toenessen FE et al (2000) A genome wide search for dyslexia loci in a large Norwegian family. Am J Hum Genet 67(4):310

47. Fagerheim T, Raeymaekers P, Tonnessen FE et al (1999) A new gene (DYX3) for dyslexia is located on chromosome 2. J Med Genet 36(9):664-669

48. Fagerheim T, Toennessen FE, Lubs HA (2002) Refinement of the dyslexia 3 locus (DYX3) on chromosome 2p15-p16 and mutation screening of candidate genes. Am J Hum Genet 71(4):461

49. Farrag AF, el-Behary AA, Kandil MR (1988) Prevalence of specific reading disability in Egypt. Lancet 2(8615):837-839

50. Fawcett AJ, Nicolson RI, Dean P (1996) Impaired performance of children with dyslexia on a range of cerebellar tasks. Ann Dyslexia 46:259-283

51. Field LL, Kaplan BJ (1998) Absence of linkage of phonological coding dyslexia to chromosome 6 p23-p21.3 in a large family data set. Am J Hum Genet 63(5):1448-1456

52. Finucci JM, Childs B (1981) Are there really more dyslexic boys than girls? In: Asara A, Geschwind N, Galaburda A et al (eds) Sex differences in dyslexia. Orton Dyslexia Society, Towson, pp $1-9$

53. Fisher SE, DeFries JC (2002) Developmental dyslexia: genetic dissection of a complex cognitive trait. Nat Rev Neurosci 3(10):767-780

54. Fisher SE, Francks C, Marlow AJ et al (2002) Independent genome-wide scans identify a chromosome 18 quantitative-trait locus influencing dyslexia. Nat Genet 30(1):86-91 
55. Fisher SE, Marlow AJ, Lamb J et al (1999) A quantitative-trait locus on chromosome $6 \mathrm{p}$ influences different aspects of developmental dyslexia. Am J Hum Genet 64(1):146-156

56. Flannery KA, Liederman J, Daly L et al (2000) Male prevalence for reading disability is found in a large sample of black and white children free from ascertainment bias. J Int Neuropsychol Soc 6(4):433-442

57. Francks C, Fisher SE, Olson RK et al (2002) Fine mapping of the chromosome 2p12-16 dyslexia susceptibility locus: quantitative association analysis and positional candidate genes SEMA4F and OTX1. Psychiatr Genet 12(1):35-41

58. Francks C, MacPhie IL, Monaco AP (2002) The genetic basis of dyslexia. Lancet Neurol 1(8):483-490

59. Francks C, Paracchini S, Smith SD et al (2004) A 77-kilobase region of chromosome $6 \mathrm{p} 22.2$ is associated with dyslexia in families from the United Kingdom and from the United States. Am J Hum Genet 75(6):1046-1058

60. Fulker DW, Cardon L, DeFries JC et al (1991) Multiple regression analysis of sib-pair data on reading to detect quantitative trait loci. Read Writ 3:299-313

61. Galaburda AM, Kemper TL (1979) Cytoarchitectonic abnormalities in developmental dyslexia: a case study. Ann Neurol 6(2):94-100

62. Galaburda AM, Menard MT, Rosen GD (1994) Evidence for aberrant auditory anatomy in developmental dyslexia. Proc Natl Acad Sci USA 91(17):8010-8013

63. Galaburda AM, Sherman GF, Rosen GD et al (1985) Developmental dyslexia: four consecutive patients with cortical anomalies. Ann Neurol 18(2):222-233

64. Gayan J, Olson RK (2001) Genetic and environmental influences on orthographic and phonological skills in children with reading disabilities. Dev Neuropsychol 20(2):483-507

65. Gayan J, Smith SD, Cherny SS et al (1999) Quantitative-trait locus for specific language and reading deficits on chromosome 6p. Am J Hum Genet 64(1):157-164

66. Geschwind N, Galaburda AM (1985) Cerebral lateralization. Biological mechanisms, associations, and pathology: I. A hypothesis and a program for research. Arch Neurol 42(5):428459

67. Gilger JW, Hanebuth E, Smith SD et al (1996) Differential risk for developmental reading disorders in the offspring of compensated versus noncompensated parents. Read Writ 8(5):407417

68. Gilger JW, Pennington BF, Defries JC (1992) A twin study of the etiology of comorbidity-attention-deficit hyperactivity disorder and dyslexia. J Am Acad Child Adolesc Psychiatry 31(2):343-348

69. Gilger JW, Pennington BF, Harbeck RJ et al (1998) A twin and family study of the association between immune system dysfunction and dyslexia using blood serum immunoassay and survey data. Brain Cogn 36(3):310-333

70. Grant ECG, Howard JM, Davies S et al (1988) Zinc-deficiency in children with dyslexia-concentrations of zinc and other minerals in sweat and hair. Br Med J 296(6622):607-609

71. Grigorenko EL, Wood FB, Golovyan L et al (2003) Continuing the search for dyslexia genes on 6p. Am J Med Genet B Neuropsychiatr Genet 118(1):89-98

72. Grigorenko EL, Wood FB, Meyer MS et al (1997) Susceptibility loci for distinct components of developmental dyslexia on chromosomes 6 and 15. Am J Hum Genet 60(1):27-39

73. Grigorenko EL, Wood FB, Meyer MS et al (2000) Chromosome $6 p$ influences on different dyslexia-related cognitive processes: further confirmation. Am J Hum Genet 66(2):715-723

74. Grigorenko EL, Wood FB, Meyer MS et al (2001) Linkage studies suggest a possible locus for developmental dyslexia on chromosome 1p. Am J Med Genet 105(1):120-129
75. Gross-Tsur V, Manor O, Shalev RS (1996) Developmental dyscalculia: prevalence and demographic features. Dev Med Child Neurol 38(1):25-33

76. Habib M (2000) The neurological basis of developmental dyslexia: an overview and working hypothesis. Brain $123(\mathrm{Pt}$ 12):2373-2399

77. Hallgren B (1950) Specific dyslexia (congenital word-blindness); a clinical and genetic study. Acta Neurol Scand Suppl 65:1-287

78. Hannula-Jouppi K, Kaminen-Ahola N, Taipale M et al (2005) The axon guidance receptor gene ROBO1 is a candidate gene for developmental dyslexia. PLoS Genet 1(4):e50

79. Harlaar N, Spinath FM, Dale PS et al (2005) Genetic influences on early word recognition abilities and disabilities: a study of 7year-old twins. J Child Psychol Psychiatry 46(4):373-384

80. Harold D, Paracchini S, Scerri T et al (2006) Further evidence that the KIAA0319 gene confers susceptibility to developmental dyslexia. Mol Psychiatry 11(12):1085-1091; 1061

81. Haslum MN, Miles TR (2007) Motor performance and dyslexia in a national cohort of 10-year-old children. Dyslexia 13(4):257-275

82. Hinshelwood J (1895) Word-blindness and visual memory. Lancet 146(3773):1564-1570

83. Hinshelwood J (1896) A case of dyslexia: a peculiar form of word-blindness. Lancet 148(3821):1451-1454

84. Hinshelwood J (1898) A case of "word" without "letter" blindness. Lancet 152(3927):422-425

85. Hinshelwood J (1899) "Letter" without "word" blindness. Lancet 153(3933):83-86

86. Hinshelwood J (1900) Congenital word-blindness. Lancet 155(4004):1506-1508

87. Hinshelwood J (1902) Congenital word-blindness, with reports of two cases. Ophthal Rev 21:91-99

88. Hinshelwood J (1902) Four cases of word-blindness. Lancet 159(4093):358-363

89. Hinshelwood J (1907) Four cases of congenital word-blindness occuring in the same family. Br Med J 1:608-609

90. Hsiung GY, Kaplan BJ, Petryshen TL et al (2004) A dyslexia susceptibility locus (DYX7) linked to dopamine D4 receptor (DRD4) region on chromosome 11p15.5. Am J Med Genet B Neuropsychiatr Genet 125(1):112-119

91. Hugdahl K, Synnevag B, Satz P (1990) Immune and autoimmune diseases in dyslexic children. Neuropsychologia 28(7):673-679

92. Humphreys P, Kaufmann WE, Galaburda AM (1990) Developmental dyslexia in women: neuropathological findings in three patients. Ann Neurol 28(6):727-738

93. Igo RP, Chapman NH, Berninger VW et al (2006) Genomewide scan for real-word reading subphenotypes of dyslexia: novel chromosome 13 locus and genetic complexity. Am J Med Genet B Neuropsychiatr Genet 141B(1):15-27

94. Kaminen N, Hannula-Jouppi K, Kestila M et al (2003) A genome scan for developmental dyslexia confirms linkage to chromosome 2p11 and suggests a new locus on 7q32. J Med Genet 40(5):340-345

95. Kaplan DE, Gayan J, Ahn J et al (2002) Evidence for linkage and association with reading disability on 6p21.3-22. Am J Hum Genet 70(5):1287-1298

96. Katusic SK, Colligan RC, Barbaresi WJ et al (2001) Incidence of reading disability in a population-based birth cohort, 19761982, Rochester, Minn. Mayo Clin Proc 76(11):1081-1092

97. Kidd T, Brose K, Mitchell KJ et al (1998) Roundabout controls axon crossing of the CNS midline and defines a novel subfamily of evolutionarily conserved guidance receptors. Cell 92(2):205-215

98. Knopik VS, Alarcon M, DeFries JC (1997) Comorbidity of mathematics and reading deficits: evidence for a genetic etiology. Behav Genet 27(5):447-453 
99. Kussmaul A (1877) Die Störungen der Sprache. Vogel, Leipzig

100. Lambert JC, Ferreira S, Gussekloo J et al (2007) Evidence for the association of the S100beta gene with low cognitive performance and dementia in the elderly. Mol Psychiatry 12(9):870-880

101. Law J, Boyle J, Harris F et al (2000) Prevalence and natural history of primary speech and language delay: findings from a systematic review of the literature. Int J Lang Commun Disord 35(2):165-188

102. Lawler A (2001) Archaeology. Writing gets a rewrite. Science 292(5526):2418-2420

103. Leonard CM, Eckert MA, Lombardino LJ et al (2001) Anatomical risk factors for phonological dyslexia. Cereb Cortex 11(2):148-157

104. Lewis B, Freebairn L, Taylor HG (2002) Correlates of spelling abilities in children with early speech sound disorders. Read Writ 15:389-407

105. Lewis C, Hitch GJ, Walker P (1994) The prevalence of specific arithmetic difficulties and specific reading difficulties in 9- to 10-year-old boys and girls. J Child Psychol Psychiatry 35(2):283-292

106. Light JG, Pennington BF, Gilger JW et al (1995) Reading-disability and hyperactivity disorder-evidence for a common genetic etiology. Dev Neuropsychol 11(3):323-335

107. Liu JX, Shi YY, Tang JX et al (2005) SNPs and haplotypes in the S100B gene reveal association with schizophrenia. Biochem Biophys Res Commun 328(1):335-341

108. Livingstone MS, Rosen GD, Drislane FW et al (1991) Physiological and anatomical evidence for a magnocellular defect in developmental dyslexia. Proc Natl Acad Sci USA 88(18):79437947

109. Luca P, Laurin N, Misener VL et al (2007) Association of the dopamine receptor D1 gene, DRD1, with inattention symptoms in families selected for reading problems. Mol Psychiatry 12(8):776-785

110. Luciano M, Lind PA, Duffy DL et al (2007) A haplotype spanning KIAA0319 and TTRAP is associated with normal variation in reading and spelling ability. Biol Psychiatry 62(7):811-817

111. Ludwig KU, Roeske D, Schumacher J et al (2008) Investigation of interaction between DCDC2 and KIAA0319 in a large German dyslexia sample. J Neural Transm 115(11):1587-1589

112. Ludwig KU, Schumacher J, Schulte-Korne G et al (2008) Investigation of the DCDC2 intron 2 deletion/compound short tandem repeat polymorphism in a large German dyslexia sample. Psychiatr Genet 18(6):310-312

113. Marino C, Citterio A, Giorda R et al (2007) Association of short-term memory with a variant within DYX1C1 in developmental dyslexia. Genes Brain Behav 6(7):640-646

114. Marino C, Giorda R, Luisa Lorusso M et al (2005) A familybased association study does not support DYX1C1 on $15 \mathrm{q} 21.3$ as a candidate gene in developmental dyslexia. Eur J Hum Genet 13(4):491-499

115. Marino C, Giorda R, Vanzin L et al (2003) No evidence for association and linkage disequilibrium between dyslexia and markers of four dopamine-related genes. Eur Child Adolesc Psychiatry 12(4):198-202

116. Marino C, Giorda R, Vanzin L et al (2004) A locus on 15q1515qter influences dyslexia: further support from a transmission/ disequilibrium study in an Italian speaking population. J Med Genet 41(1):42-46

117. Marlow AJ, Fisher SE, Francks C et al (2003) Use of multivariate linkage analysis for dissection of a complex cognitive trait. Am J Hum Genet 72(3):561-570

118. McArthur GM, Hogben JH, Edwards VT et al (2000) On the "specifics" of specific reading disability and specific language impairment. J Child Psychol Psychiatry 41(7):869-874
119. Meaburn EL, Harlaar N, Craig IW et al (2008) Quantitative trait locus association scan of early reading disability and ability using pooled DNA and 100K SNP microarrays in a sample of 5760 children. Mol Psychiatry 13(7):729-740

120. Meda SA, Gelernter J, Gruen JR et al (2008) Polymorphism of DCDC2 reveals differences in cortical morphology of healthy individuals-A preliminary voxel based morphometry study. Brain Imaging Behav 2(1):21-26

121. Meng H, Smith SD, Hager K et al (2005) DCDC2 is associated with reading disability and modulates neuronal development in the brain. Proc Natl Acad Sci USA 102(47):1705317058

122. Meng HY, Hager K, Held M et al (2005) TDT-association analysis of EKN1 and dyslexia in a Colorado twin cohort. Hum Genet 118(1):87-90

123. Morgan WP (1896) A case of congenital word-blindness (inability to learn to read). Br Med J 2:1543-1544

124. Morris DW, Robinson L, Turic D et al (2000) Family-based association mapping provides evidence for a gene for reading disability on chromosome 15q. Hum Mol Genet 9(5):843-848

125. Mukhopadhyay M, Pelka P, DeSousa D et al (2002) Cloning, genomic organization and expression pattern of a novel Drosophila gene, the disco-interacting protein 2 (dip2), and its murine homolog. Gene 293(1-2):59-65

126. Nicolson RI, Fawcett AJ, Dean P (2001) Developmental dyslexia: the cerebellar deficit hypothesis. Trends Neurosci 24(9):508-511

127. Nopola-Hemmi J, Myllyluoma B, Haltia T et al (2001) A dominant gene for developmental dyslexia on chromosome 3. J Med Genet 38(10):658-664

128. Nopola-Hemmi J, Taipale M, Haltia T et al (2000) Two translocations of chromosome $15 \mathrm{q}$ associated with dyslexia. J Med Genet 37(10):771-775

129. Norton N, Heiervang E, Hamshere M et al (2000) Suggestive evidence of linkage with reading disability in a large Norwegian family. Am J Med Genet 96(4):556

130. Nothen MM, Schulte-Korne G, Grimm T et al (1999) Genetic linkage analysis with dyslexia: evidence for linkage of spelling disability to chromosome 15. Eur Child Adolesc Psychiatry 8(Suppl 3):56-59

131. Oliver BR, Plomin R (2007) Twins' Early Development Study (TEDS): a multivariate, longitudinal genetic investigation of language, cognition and behavior problems from childhood through adolescence. Twin Res Hum Genet 10(1):96-105

132. Olton DS, Papas BC (1979) Spatial memory and hippocampal function. Neuropsychologia 17(6):669-682

133. Paracchini S, Scerri T, Monaco AP (2007) The genetic lexicon of dyslexia. Annu Rev Genomics Hum Genet 8:57-79

134. Paracchini S, Steer CD, Buckingham LL et al (2008) Association of the KIAA0319 dyslexia susceptibility gene with reading skills in the general population. Am J Psychiatry 165(12):15761584

135. Paracchini S, Thomas A, Castro S et al (2006) The chromosome $6 \mathrm{p} 22$ haplotype associated with dyslexia reduces the expression of KIAA0319, a novel gene involved in neuronal migration. Hum Mol Genet 15(10):1659-1666

136. Petrill SA, Deater-Deckard K, Thompson LA et al (2006) Reading skills in early readers: genetic and shared environmental influences. J Learn Disabil 39(1):48-55

137. Petryshen TL, Kaplan BJ, Fu Liu M et al (2001) Evidence for a susceptibility locus on chromosome $6 \mathrm{q}$ influencing phonological coding dyslexia. Am J Med Genet 105(6):507-517

138. Petryshen TL, Kaplan BJ, Hughes ML et al (1999) Linkage and association analyses of GABA receptor, dopamine receptor, and dopamine transporter genes in phonological coding dyslexia. Mol Psychiatry 4:S85 
139. Petryshen TL, Kaplan BJ, Hughes ML et al (2002) Supportive evidence for the DYX3 dyslexia susceptibility gene in Canadian families. J Med Genet 39(2):125-126

140. Petryshen TL, Kaplan BJ, Liu MF et al (2000) Absence of significant linkage between phonological coding dyslexia and chromosome 6p23-21.3, as determined by use of quantitativetrait methods: confirmation of qualitative analyses. Am J Hum Genet 66(2):708-714

141. Peyrard-Janvid M, Anthoni H, Onkamo P et al (2004) Fine mapping of the 2p11 dyslexia locus and exclusion of TACR1 as a candidate gene. Hum Genet 114(5):510-516

142. Poelmans G, Engelen JJ, Van Lent-Albrechts J et al (2009) Identification of novel dyslexia candidate genes through the analysis of a chromosomal deletion. Am J Med Genet B Neuropsychiatr Genet 150B(1):140-147

143. Pugh KR, Sandak R, Frost SJ et al (2005) Examining reading development and reading disability in English language learners: potential contributions from functional neuroimaging. Learn Disabil Res Pract 20(1):24-30

144. Rabin M, Wen XL, Hepburn M et al (1993) Suggestive linkage of developmental dyslexia to chromosome 1p34-p36. Lancet 342(8864): 178

145. Ramus F, Rosen S, Dakin SC et al (2003) Theories of developmental dyslexia: insights from a multiple case study of dyslexic adults. Brain 126(Pt 4):841-865

146. Raskind WH, Igo RP, Chapman NH et al (2005) A genome scan in multigenerational families with dyslexia: identification of a novel locus on chromosome $2 \mathrm{q}$ that contributes to phonological decoding efficiency. Mol Psychiatry 10(7):699-711

147. Reed MA (1989) Speech perception and the discrimination of brief auditory cues in reading disabled children. J Exp Child Psychol 48(2):270-292

148. Richlan F, Kronbichler M, Wimmer H (2009) Functional abnormalities in the dyslexic brain: a quantitative meta-analysis of neuroimaging studies. Hum Brain Mapp 10:3299-3308

149. Roche S, Cassidy F, Zhao C et al (2007) Candidate gene analysis of 21q22: support for S100B as a susceptibility gene for bipolar affective disorder with psychosis. Am J Med Genet B Neuropsychiatr Genet 144B(8):1094-1096

150. Rosen GD, Bai J, Wang Y et al (2007) Disruption of neuronal migration by RNAi of Dyx1c1 results in neocortical and hippocampal malformations. Cereb Cortex 17(11):2562-2572

151. Rumsey JM, Nace K, Donohue B et al (1997) A positron emission tomographic study of impaired word recognition and phonological processing in dyslexic men. Arch Neurol 54(5):562-573

152. Rutter M, Yule W (1975) The concept of specific reading retardation. J Child Psychol Psychiatry 16(3):181-197

153. Sawyer D, Krishnamani R, Hannig VL et al (1998) Genetic analysis of phonologic core deficit dyslexia (PCDD). Am J Hum Genet 63(A307)

154. Scerri TS, Fisher SE, Francks C et al (2004) Putative functional alleles of DYX1C1 are not associated with dyslexia susceptibility in a large sample of sibling pairs from the UK. J Med Genet 41(11):853-857

155. Schulte-Korne G (2001) Annotation: Genetics of reading and spelling disorder. J Child Psychol Psychiatry 42(8):985-997

156. Schulte-Korne G, Deimel W, Muller K et al (1996) Familial aggregation of spelling disability. J Child Psychol Psychiatry 37(7):817-822

157. Schulte-Korne G, Grimm T, Nothen MM et al (1998) Evidence for linkage of spelling disability to chromosome 15. Am J Hum Genet 63(1):279-282

158. Schumacher J, Anthoni H, Dahdouh F et al (2006) Strong genetic evidence of DCDC2 as a susceptibility gene for dyslexia. Am J Hum Genet 78(1):52-62
159. Schumacher J, Hoffmann P, Schmal C et al (2007) Genetics of dyslexia: the evolving landscape. J Med Genet 44(5):289-297

160. Schumacher J, Konig IR, Plume E et al (2006) Linkage analyses of chromosomal region 18p11-q12 in dyslexia. J Neural Transm 113(3):417-423

161. Schumacher J, Konig IR, Schroder T et al (2008) Further evidence for a susceptibility locus contributing to reading disability on chromosome 15q15-q21. Psychiatr Genet 18(3):137-142

162. Semrud-Clikeman M, Biederman J, Sprich-Buckminster S et al (1992) Comorbidity between ADDH and learning disability: a review and report in a clinically referred sample. J Am Acad Child Adolesc Psychiatry 31(3):439-448

163. Seshadri S, DeStefano AL, Au R et al (2007) Genetic correlates of brain aging on MRI and cognitive test measures: a genomewide association and linkage analysis in the Framingham Study. BMC Med Genet 8(Suppl 1):S15

164. Shalev RS, Auerbach J, Manor O et al (2000) Developmental dyscalculia: prevalence and prognosis. Eur Child Adolesc Psychiatry 9 (Suppl 2):1158-1164

165. Shalev RS, Gross-Tsur V (2001) Developmental dyscalculia. Pediatr Neurol 24(5):337-342

166. Shaywitz BA, Shaywitz SE, Pugh KR et al (2002) Disruption of posterior brain systems for reading in children with developmental dyslexia. Biol Psychiatry 52(2):101-110

167. Shaywitz SE (1998) Dyslexia. N Engl J Med 338(5):307-312

168. Shaywitz SE, Shaywitz BA, Pugh KR et al (1998) Functional disruption in the organization of the brain for reading in dyslexia. Proc Natl Acad Sci USA 95(5):2636-2641

169. Sherman DK, Iacono WG, McGue MK (1997) Attention-deficit hyperactivity disorder dimensions: a twin study of inattention and impulsivity-hyperactivity. J Am Acad Child Adolesc Psychiatry 36(6): 745-753

170. Shriberg LD, Tomblin JB, McSweeny JL (1999) Prevalence of speech delay in 6-year-old children and comorbidity with language impairment. J Speech Lang Hear Res 42(6):1461-1481

171. Simos PG, Breier JI, Fletcher JM et al (2000) Cerebral mechanisms involved in word reading in dyslexic children: a magnetic source imaging approach. Cereb Cortex 10(8):809-816

172. Simos PG, Breier JI, Fletcher JM et al (2000) Brain activation profiles in dyslexic children during non-word reading: a magnetic source imaging study. Neurosci Lett 290(1):61-65

173. Simos PG, Breier JI, Wheless JW et al (2000) Brain mechanisms for reading: the role of the superior temporal gyrus in word and pseudoword naming. Neuroreport 11(11):2443-2447

174. Smith SD, Kimberling WJ, Pennington B (1991) Screening for multiple genes influencing dyslexia. Read Writ Interdiscip J 3:285-298

175. Smith SD, Kimberling WJ, Pennington BF et al (1983) Specific reading disability: identification of an inherited form through linkage analysis. Science 219(4590): 1345-1347

176. Smith SD, Pennington BF, Kimberling WJ et al (1990) Familial dyslexia: use of genetic linkage data to define subtypes. J Am Acad Child Adolesc Psychiatry 29(2):204-213

177. Snowling MJ (1981) Phonemic deficits in developmental dyslexia. Psychol Res 43(2):219-234

178. Stein CM, Schick JH, Taylor HG et al (2004) Pleiotropic effects of a chromosome 3 locus on speech-sound disorder and reading. Am J Hum Genet 74(2):283-297

179. Stein J, Walsh V (1997) To see but not to read: the magnocellular theory of dyslexia. Trends Neurosci 20(4):147-152

180. Steller H, Fischbach KF, Rubin GM (1987) Disconnected: a locus required for neuronal pathway formation in the visual system of Drosophila. Cell 50(7):1139-1153

181. Stephenson S (1907) Six cases of congenital word-blindness affecting three generations of one family. Ophthalmoscope $5: 482-484$ 
182. Stevenson J, Graham P, Fredman G et al (1987) A twin study of genetic influences on reading and spelling ability and disability. J Child Psychol Psychiatry 28(2):229-247

183. Stoodley CJ, Fawcett AJ, Nicolson RI et al (2005) Impaired balancing ability in dyslexic children. Exp Brain Res 167(3): 370-380

184. Taipale M, Kaminen N, Nopola-Hemmi J et al (2003) A candidate gene for developmental dyslexia encodes a nuclear tetratricopeptide repeat domain protein dynamically regulated in brain. Proc Natl Acad Sci USA 100(20):11553-11558

185. Tallal P (1980) Auditory temporal perception, phonics, and reading disabilities in children. Brain Lang 9(2):182-198

186. Taylor KE, Higgins CJ, Calvin CM et al (2000) Dyslexia in adults is associated with clinical signs of fatty acid deficiency. Prostaglandins Leukot Essent Fatty Acids 63(1-2):75-78

187. Temple E, Poldrack RA, Salidis J et al (2001) Disrupted neural responses to phonological and orthographic processing in dyslexic children: an fMRI study. Neuroreport 12(2):299-307

188. Thomas CJ (1905) Congenital "word-blindness" and its treatment. Ophthalmoscope 3:380-385

189. Threlkeld SW, McClure MM, Bai J et al (2007) Developmental disruptions and behavioral impairments in rats following in utero RNAi of Dyx1c1. Brain Res Bull 71(5):508-514

190. Tomblin JB, Buckwalter PR (1998) Heritability of poor language achievement among twins. J Speech Lang Hear Res 41(1):188-199

191. Tomblin JB, Records NL, Buckwalter P et al (1997) Prevalence of specific language impairment in kindergarten children. J Speech Lang Hear Res 40(6): 1245-1260

192. Tonnessen FE, Lokken A, Hoien T et al (1993) Dyslexia, lefthandedness, and immune disorders. Arch Neurol 50(4):411-416

193. Turic D, Robinson L, Duke M et al (2003) Linkage disequilibrium mapping provides further evidence of a gene for reading disability on chromosome 6p21.3-22. Mol Psychiatry 8(2):176185

194. Tzenova J, Kaplan BJ, Petryshen TL et al (2004) Confirmation of a dyslexia susceptibility locus on chromosome 1p34-p36 in a set of 100 Canadian families. Am J Med Genet B Neuropsychiatr Genet 127(1):117-124

195. Vincent A, Deacon R, Dalton P et al (2002) Maternal antibodymediated dyslexia? Evidence for a pathogenic serum factor in a mother of two dyslexic children shown by transfer to mice using behavioural studies and magnetic resonance spectroscopy. J Neuroimmunol 130(1-2):243-247

196. Vogel SA (1990) Gender differences in intelligence, language, visual-motor abilities, and academic achievement in students with learning disabilities: a review of the literature. J Learn Disabil 23(1):44-52

197. Vogler GP, DeFries JC, Decker SN (1985) Family history as an indicator of risk for reading disability. $\mathrm{J}$ Learn Disabil 18(7):419-421
198. Wang Y, Paramasivam M, Thomas A et al (2006) DYX1C1 functions in neuronal migration in developing neocortex. Neuroscience 143(2):515-522

199. Ward M, McCann C, DeWulf M et al (2003) Distinguishing between directional guidance and motility regulation in neuronal migration. J Neurosci 23(12):5170-5177

200. Wigg KG, Couto JM, Feng Y et al (2004) Support for EKN1 as the susceptibility locus for dyslexia on $15 \mathrm{q} 21$. Mol Psychiatry 9(12):1111-1121

201. Wigg KG, Couto JM, Feng Y et al (2005) Investigation of the relationship of attention deficit hyperactivity disorder to the EKN1 gene on chromosome 15q21. Sci Stud Read 9(3):261-283

202. Wigg KG, Feng Y, Crosbie J et al (2008) Association of ADHD and the Protogenin gene in the chromosome $15 \mathrm{q} 21.3$ reading disabilities linkage region. Genes Brain Behav 7(8):877-886

203. Willcutt EG, Pennington BF (2000) Comorbidity of reading disability and attention-deficit/hyperactivity disorder: differences by gender and subtype. J Learn Disabil 33(2):179-191

204. Willcutt EG, Pennington BF, DeFries JC (2000) Twin study of the etiology of comorbidity between reading disability and attention-deficit/hyperactivity disorder. Am J Med Genet 96(3):293-301

205. Willcutt EG, Pennington BF, Olson RK et al (2007) Understanding comorbidity: a twin study of reading disability and attention-deficit/hyperactivity disorder. Am J Med Genet B Neuropsychiatr Genet 144B(6):709-714

206. Williams J, O'Donovan MC (2006) The genetics of developmental dyslexia. Eur J Hum Genet 14(6):681-689

207. Wolf M, Bowers PG (1999) The double-deficit hypothesis for the developmental dyslexias. J Educ Psychol 91(3):415-438

208. Wolf M, Bowers PG (2000) Naming-speed processes and developmental reading disabilities: an introduction to the special issue on the double-deficit hypothesis. J Learn Disabil 33(4):322-324

209. World Health Organization (1993) The ICD-10 classification of mental and behavioural disorders: diagnostic criteria for research. World Health Organization, Geneva

210. Ylisaukko-Oja T, Peyrard-Janvid M, Lindgren CM et al (2005) Family-based association study of DYX1C1 variants in autism. Eur J Hum Genet 13(1):127-130

211. Yu G, Zerucha T, Ekker M et al (2001) Evidence that GRIP, a PDZ-domain protein which is expressed in the embryonic forebrain, co-activates transcription with DLX homeodomain proteins. Brain Res Dev Brain Res 130(2):217-230

212. Zerbin-Rüdin E (1967) Kongenitale Worblindheit oder spezifische dyslexie (congenital word-blindness). Bull Orton Soc 17:47-56

213. Ziegler A, Konig IR, Deimel W et al (2005) Developmental dyslexia-recurrence risk estimates from a german bi-center study using the single proband sib pair design. Hum Hered 59(3):136-143 